\title{
Ewa KRUPNIK
}

\section{POWSTANIE I ORGANIZACJA KRAKOWSKIEGO BISKUPIEGO KOMITETU POMOCY DLA DOTKNIĘTYCH KLĘSKĄ WOJNY}

\author{
- I. W PRZEDEDNIU WOJNY
}

\section{GALICJA PRZED 1914 ROKIEM}

W przededniu I wojny światowej, sytuację w Galicji charakteryzowała z jednej strony szeroko pojęta autonomia, a $z$ drugiej zacofanie gospodarcze regionu. Brak jakiegokolwiek myślenia strategicznego w dziedzinie gospodarki boleśnie odbijał się na całym regionie. Galicja postrzegana była jako kraj nędzy chłopskiej, gdzie gospodarstwa poniżej 5 ha stanowily $80 \%$ wszystkich gospodarstw ${ }^{1}$. Przemysł skoncentrowany był tylko w kilku rejonach, co jeszcze bardziej pogłębiało problemy gospodarcze tej prowincji.

W XIX stuleciu nastąpił ogromny wzrost liczby ludności. Na ziemiach polskich odnotowano do I wojny światowej jeden z największych przyrostów demograficznych w Europie. W 1910 roku Galicja zajmowała terytorium o powierzchni 78 tys. $\mathrm{km}^{2} \mathrm{z}$ liczbą 8026 ludności, gdzie gęstość zaludnienia wynosiła 102 osoby na $1 \mathrm{~km}^{22}$. Począwszy od drugiej połowy XIX w. ze wzrostem ludności wiązały się ruchy migracyjne na niespotykaną wówczas skalę. Na początku XX wieku wyróżniano dwa główne typy migracji: wewnętrzna np. ze wsi do miasta oraz zewnętrzna

' J. Holzer, J. Molenda, Polska w piemszej wojnie światowej, Warszawa 1973, s. 24-25. Głównym problemem gospodarczym Galicji była małorolność. Rzadko spotykało się gospodarstwa, które posiadałyby powyżej 20 ha. Taka sytuacja podobnie jak w innych rozbiorach przyczyniała się do wyzysku biedniejszych chłopów i ich uzależnienia od bogatszych gospodarzy. Dodatkowo majątki obszarników stanowiły $40 \%$ ziem.

${ }^{2}$ A. Chwalba, Historia Polski 1795-1918, Kraków 2000, s. 24-25. Dla porównania Królestwo Polskie zajmowało terytorium 123 tys. km², na którym zamieszkiwało 12129 osób. 
do krajów mniej przeludnionych ${ }^{3}$. Przyczyn migracji należy upatrywać przede wszystkim w poszukiwaniach zarobku oraz lepszych warunków życia. Największe liczby imigrantów przyjmowały wówczas miasta.

Migracje bezpośrednio łączyły się z wprowadzeniem nowych środków podróżowania. Jednakże wprowadzenie ich nie zawsze łączyło się z poprawą szybkości podróżowania w zaborach. Stan dróg był wszędzie tragiczny. Dla przykładu w dobie autonomii galicyjskiej w największych ośrodkach miejskich podejmowano się wprowadzenia trwałej brukowej nawierzchni. Proces ten jednak przebiegał stopniowo. Dlatego w Galicji jeszcze na krótko przed wybuchem wojny wyłącznie drogi cesarskie posiadały utwardzoną nawierzchnię. Jakość podróżowania z pewnością poprawiła się dzięki podróży koleją. Ten środek lokomocji wpłynął na transport ludzi i towarów. Kolej zrewolucjonizowała także samo podejście ludzi do podróżowania i wpłynęła znacząco na szybkość przemieszczania się 4 .

W Galicji i Lodomerii, przede wszystkim na wsi, poziom edukacji był stosunkowo niski. Wśród ludności przeważał analfabetyzm (aż 48\% ludności zaboru austriackiego w 1910 roku - wyłączając mieszkańców Krakowa i Lwowa - nie umiało pisać) $)^{5}$ I choć od końca XIX wieku dostrzegamy wyższy rozwój zarówno powszechnej jak irobowiązkowej szkoły, to jednak w latach 1910-1911 na 2 miliony dzieci (w wieku od 5 do 15 lat) nauką było objętych zaledwie $1,3 \mathrm{mln}^{6}$.

Zacofanie społeczeństwa zwłaszcza w Galicji wiązało się z wszechogarniającą biedą. Przewodnią myślą polskiego ludu było najczęściej zadawane pytanie o przetrwanie. Ludność polska nie zajmowała się kwestią higieny czy troską o zdrowie. Wręcz przeciwnie przywiązywanie większej wagi do tego typu spraw traktowano jako dziwactwo. Stąd stan sanitarny zaborów przedstawiał się katastrofalnie. Zasadniczym problemem zarówno miast i wsi był brud. Zmiany w tym zakresie przebiegały bardzo wolno w zależności od zaboru. Najszybciej wprowadzono je w zaborze pruskim. Zmiana mentalności w zaborze pruskim jak i wprowadzenie policji sanitarnej i porządkowej spowodowały, że już przed 1914 rokiem miasta Polski zachodniej były zbliżone do standardów zachodnioeuropejskich. Inaczej ta kwestia przedstawiała się w zaborze rosyjskim czy austriackim. W tym ostatnim wszystkie wprowadzane zmiany sanitarno-higieniczne przebiegały sukcesywnie jedynie w miastach. Trzeba przyznać, że przemiany w mentalności mas ludowych następowały stosunkowo wolno. Jeszcze przed wojną obraz polskich wsi wskazywał na to, że galicyjska ludność nie wykazywała jakiegokolwiek zainteresowania wobec przestrzegania zasad higieny'.

${ }^{3}$ J. Pajewski, Historia Powszechna, s. 8.

${ }^{7}$ A. Chwalba, Historia..., dz. cyt., s. 64 n.

${ }_{5}^{5}$ J. Holzer, J. Molenda, Polska..., dz. cyt., s. 25.

${ }^{6}$ Tamże, s. 28.

${ }^{7}$ A. Chwalba, Historia..., dz. cyt., s. 30-33. W jeszcze gorszej kondycji od galicyjskiej prowincji stały kresy, tzw. „Ziemie zabrane”. Przykładem kompletnego niechlujstwa było powiedzenie „,́winie tu jadły czy Litwa popasowała". 
Jak już wspomnieliśmy zmiany dotyczące zasad higieny w mentalności ludzkiej zachodziły niezwykle wolno. Pierwsze wzmianki o mydle na wsi galicyjskiej zanotowano dopiero pod koniec XIX wieku. Podobnie było w kwestii dbania o odzież i bieliznę ${ }^{8}$. Edukacja $w$ tym zakresie przebiegała bardzo wolno. Jeszcze w latach międzywojennych zachęcano ludność do zmiany koszuli raz w tygodniu i codziennego mycia mydlem. W sferach robotniczych ten proces przebiegał znacznie szybciej niż na wsi9.

Wyrazem tych zachowań była także niechęć do opieki medycznej. Jedynie w zaborze pruskim ludność chętnie korzystała z porad miejscowych lekarzy. Tak znaczne różnice $w$ podejściu do opieki lekarskiej prawdopodobnie wynikały $\mathrm{z}$ wyższego stopnia cywilizacyjnego zaboru pruskiego. Inaczej sytuacja przedstawiała się w zaborze galicyjskim. Najczęściej masy ludu po pomoc kierowały się do miejscowych znachorów, babek czy zielarzy. Medyków ludowych obdarzano ogromnym zaufaniem w przeciwieństwie do lekarzy, o których zazwyczaj wypowiadano się nieprzychylnie. W 1914 roku z pomocy opieki lekarskiej zaborów galicyjskiego i rosyjskiego skorzystało zaledwie 30\% całej społeczności. Podobnie jak do lekarzy miejscowa ludność odnosiła się z niechęcią do szpitali ${ }^{10}$.

$\mathrm{Na}$ początku XX wieku dzięki rozbudowie sieci wodociągów i kanalizacji zapobiegano na większą skalę chorobom i epidemiom. Dzięki tym zabiegom odnotowano w miastach wyraźny spadek śmiertelności. Budowa łazienek oraz poprawa jakości wody pozwoliły na prowadzenie skutecznej walki z epidemiami. Ponadto zarówno władze samorządowe zaboru pruskiego jak i austriackiego starały się jeszcze przed wojną wpłynąc pozytywnie na sytuację zdrowotną mieszkańców ${ }^{11}$.

Długość i jakość życia mas ludowych zależały od ilości pożywienia. Nierówność w dostępie do pożywienia powodowała ogromne dysproporcje w obrębie społeczeństwa. Największe niedobory żywności odnotowywano na wsi. W XIX wieku w całej Europie występowały fale głodu. Z początkiem XX wieku w zaborze galicyjskim nie było już przypadków śmierci głodowej, jednakże zdarzały się ciężkie przednówki. Trzeba dodać, że migracje pozytywnie wpłynęły na dostęp do pożywienia, gdyż coraz rzadziej spotykano się z przeludnieniem wsi. Ponadto wprowadzone zmiany m.in. innowacje w technice upraw wpłynęły na wzrost wydajności ziemi. Ponadto wzrost produkcji był szybszy od przyrostu naturalnego. Wzrosła także kaloryczność pożywienia, jednak posiłki rzeszy rodzin chłopskich nadal były nie urozmaicone ${ }^{12}$.

\footnotetext{
${ }^{8}$ Tamże, s. 33 n. Na początku XX wieku odchodzono od tradycji dziedziczenia ubioru po rodzicach.

${ }^{9}$ Tamże, s. $33 \mathrm{n}$.

${ }^{10}$ Tamże, s. $40 \mathrm{n}$.

${ }^{11}$ Tamże, s. 43. W miastach władze przeznaczały znaczne nakłady finansowe na walkę z chorobami.

${ }^{12}$ A. Chwalba, Historia. , s. 44. Pomimo wprowadzenia ziemniaków jadłospis chłopski był bardzo ubogi. Mięso jadano głownie w święta, chleb wypiekano raz w tygodniu. Spożywano także znaczne ilości ka-
} pusty, grochu i fasoli. 
Podobnie jak w XIX wieku, tak i w początkach XX wieku, najczęstszym przykładem rodziny polskiej była rodzina jednopokoleniowa (rodzice oraz nieletnie dzieci). Obraz rodziny polskiej zbliżony był do ówczesnego wzorca europejskiego. Rodziny były patrymonialne, na ich czele stał ojciec rodziny. Wszystko, począwszy od żony, dzieci i dóbr materialnych, było oddane jego kontroli. Mąż i ojciec był największym autorytetem $w$ rodzinie. To on sprawował nadzór nad domem i wychowaniem dzieci. Zarówno w rodzinie chłopskiej, ziemiańskiej czy mieszczańskiej kobieta stała w cieniu mężczyzny. Rola kobiet w podanych modelach rodziny różniła się w pewnych aspektach ${ }^{13}$. Ponadto kobieta miała być zawsze dobrą, poczciwą i religijną gospodynią lub panią domu. Podobnie jak w XIX wieku tak i przed 1914 rokiem panował stereotyp, że największym sukcesem kobiety jest powszechnie szanowany małżonek. Ponadto jedynie w rodzinach robotniczych nie dokonywano wyboru przyszłego małżonka dla córek. Wiązało się to ze swobodą poruszania się $\mathrm{w}$ mieście oraz $\mathrm{z}$ łatwiejszym nawiązywaniem kontaktów. Jednakże w środowisku robotniczym, kobiety o wiele rzadziej decydowały się na zamążpójście $^{14}$.

Ogromną rolę w życiu Polaków odgrywała religia katolicka. Była ona mocno zakorzeniona w tradycji i kulturze. Warstwa chłopska, zarówno obrządku katolickiego jak i unickiego, powszechnie uczestniczyła w nabożeństwach niedzielnych i świątecznych jak i w innych praktykach religijnych. Zarówno katolikom obrządku łacińskiego jak i unickiego niska wiedza religijna nie przeszkadzała w praktykach religijnych. Jeszcze przed I wojną światową w świadomości religijnej katolików sakramenty łączyły się bezpośrednio z zabobonami i magią. Ponadto często spotykano się z powszechną wiarą w duchy. Na początku XX wieku charakterystyczną cechą polskiej religijności był kult maryjny oraz pielgrzymki do miejsc świętych. Najczęściej organizowano pielgrzymki na Jasna Górę, która była symbolem duchowej stolicy Polski. W Galicji dzięki pracy kapłanów-społeczników podniósł się poziom edukacji społeczno-oświatowej wśród wiernych.

Na początku XX wieku pojęcie narodu miało inne znaczenie niż sto lat wcześniej. Przede wszystkim dlatego, że nie łączono go wyłącznie ze stanem szlacheckim (szlachecki naród sarmatów). W praktyce przed wybuchem I wojny światowej doszło do ewolucji poglądów w kwestii świadomości narodowej. Z narodem polskim utożsamiali się zarówno mieszkańcy miast jak i miasteczek oraz robotnicy. $\mathrm{U}$ tych ostatnich dzięki dynamice miasta proces integracji $\mathrm{z}$ narodem polskim zachodził najszybciej. Kwestia ta inaczej prezentowała się w przypadku chłopów. Z pewnością polskojęzyczni chłopi, którzy mieszkali w środowisku polskim stawali się (często nieświadomie) częścią polskiego narodu. Kształtowanie się polskiej

\footnotetext{
${ }^{13}$ Tamże, s. 108 n. Na przykład, w przeciwieństwie do rodziny chłopskiej, w rodzinach ziemiańskich ukształtowal się na początku XX wieku model Matki Polki.

${ }^{14}$ Temat ten szerzej omawia praca: A. Żarnowska, Kobieta i praca w XIX i XX wieku, Warszawa 2000.
} 
świadomości narodowej związane było poniekąd z likwidacją różnic prawnych. Zniesienie aktów prawnych dotyczących poddaństwa i gwarancja ziemi przybliżały chłopów do spraw narodowych. Największe bariery integracji występowały w zaborze austriackim. Spowodowane to było silnym przywiązaniem do monarchii austriackiej, co kolidowało z poczuciem polskości. Jednak procesy integracyjne tj. migracje, przenikanie chłopów do innych warstw spowodowały, że z początkiem $\mathrm{XX}$ wieku coraz więcej wsi przechodziło proces unaradawiania ${ }^{15}$. Co więcej, $\mathrm{z}$ chwilą wybuchu pierwszej wojny światowej, przeważająca większość polskojęzycznych chłopów uległa procesowi unaradawiania. Dodatkowo ważną rolę w unarodowieniu wszystkich warstw społecznych posiadał Kościół katolicki. Kościół poniekąd stał się instytucją narodową. Ponadto od początku XX wieku w świadomości narodu silnie funkcjonował termin Polak-katolik. Wspomniany wcześniej kult maryjny zwłaszcza pielgrzymki do Pani Jasnogórskiej odegrały niemałą rolę w procesie integracji narodu polskiego.

Natomiast inną drogą przebiegał proces narodowotwórczy na ziemiach Galicji wschodniej i ,ziem zabranych". Tereny te zamieszkiwane były przez ludność mieszaną zarówno pod względem wyznaniowym jak i językowym. Ponadto na wspomnianą ludność oddziaływali zarówno przedstawiciele narodu polskiego jak $\mathrm{i}$ innych narodowości. Stąd na początku XX wieku w wyniku procesów narodowotwórczych tzw. ojczyzny Polaków stały się ojczyznami innych narodów ${ }^{16}$.

Narodziny nowych narodów, szczególnie ukraińskiego i białoruskiego, spowodowały skurczenie etnicznego obszaru polskiego narodu. Przyczyn konfliktu pomiędzy Polakami a narodami kresowymi było kilka. Do jednego z najważniejszych należało nie dostrzeganie procesu kształtowania się nowych narodów na ziemiach zabranych. Stąd na początku XX wieku wśród Polaków krążyło przekonanie, że Galicja wschodnia to polska kraina, którą zamieszkiwały różne rody narodu polskiego. Jednakże blisko roku 1914 społeczeństwo polskie zaczęło dostrzegać nowe narody, które uformowały się na kresach. Nowe narody powstały wbrew interesom narodu polskiego, dlatego nie dopuszczano do uznania ich roszczeń terytorialnych. Taka postawa musiała prowadzić do konfliktu. W dodatku Polakom nie udało się przeforsować pomysłu zachowania jedności narodowej, co doprowadziło pod koniec wojny do eskalacji konfliktu ${ }^{17}$.

Społeczeństwo polskie zarówno w Galicji jak i w pozostałych zaborach podchodziło biernie do nadchodzącego konfliktu międzynarodowego. Nie opowiadano się po żadnej ze stron, obawiano się natomiast skutków, jakie wojna miała ze sobą przynieść. Wkrótce dramatem polskiego narodu stały się bratobójcze walki i pożoga wojenna ${ }^{18}$.

\footnotetext{
${ }^{15}$ A. Chwalba, Historia, dz. cyt., s. 154-156.

${ }^{16}$ Tamże, s. 163.

${ }^{17}$ A. Chwalba, Historia ..., dz. cyt., s. 165.

${ }^{18}$ Tamże, s. 50.
} 


\section{KRAKÓW PRZED WYBUCHEM I WOJNY ŚWIATOWEJ}

Kraków na początku XX wieku pod względem liczby mieszkańców znajdował się w grupie sześciu najważniejszych miast tzw. „Przedlitawii”. Jeszcze kilkadziesiąt lat wcześniej był mało znaczącym miasteczkiem, kompletnie nie liczącym się na arenie galicyjskiej. Jednakże od 1866 roku, kiedy to ówczesny prezydent Józef Dietl zapowiedział szereg zmian i modernizacji, mieszkańcy Krakowa i jego okręgu doświadczyli wielkiego skoku rozwojowego miasta ${ }^{19}$.

Jeszcze przed wybuchem I wojny światowej, około 1910 roku, rozpoczęła się na szeroką skalę akcja rozszerzania granic miasta. Kraków pod względem terytorialnym na przestrzeni kilkunastu lat stał się ,wielkim miastem" ${ }^{20}$. Rozszerzyło się ono pod względem zajmowanego terytorium, co dało w rezultacie znaczne powiększenie liczby ludności ${ }^{21}$. Jednakże Kraków nadal pozostawał fortecą. Pomimo tego, że na początku XX wieku austriackie władze wojskowe przesunęły zachodnią linię forteczną Krakowa ${ }^{22}$, miasto nadal nie mogło się $w$ pełni rozwijać ${ }^{23}$. $Z$ drugiej strony rozwój miasta przyczyniał się do jego przeobrażenia $\mathrm{z}$ miasteczka rolniczego w miasto o określonym zasięgu przemysłowym. Trzeba tu dodać, że jak na warunki Krakowa przemyșł rozwijał się pomyślnie choć nie spektakularnie ${ }^{24}$. Natomiast handel i usługi były dobrze rozwinięte. Istniało w Krakowie wiele banków oraz instytucji ubezpieczeniowych (Florianka) ${ }^{25}$. W mieście funkcjonowała także Izba Handlowa i Przemysłowa na Galicję Zachodnią ${ }^{26}$.

Nie można także pominąć zmian, jakie zaszły w samym mieście i to zarówno pod względem społecznym, kulturalnym czy też politycznym. Kraków nie był już zaliczany do małomiasteczkowych prowincji, lecz rywalizował z innymi miastami monarchii. Przede wszystkim podobnie jak inne miasta Monarchii Kraków posia-

${ }^{19}$ J. Bieniarzówna, J. Malecki, Dzieje Krakowa. Kraków w latach 1796-1918, t. 3, Kraków 1979, s. 355; J. M. Małecki, Życie gospodarcze Krakowa w czasie wielkiej wojny 1914-1918, [w:] Kraków w czasie I wojny światowej-materiały z sesji naukowej z okazji dni Krakowa w roku 1988, Kraków 1990, s. 54.

${ }_{20}$ J. Bieniarzówna, J. Małecki, Dzieje Krakowa..., dz. cyt., s. 357-361. Autor przedstawia "historyczny" rozwój Krakowa. Wychodzi od daty 19 IX 1907, kiedy to na posiedzeniu Rady Miasta przyjęto projekt ustawy o rozszerzeniu granic miasta. Ustawa podpisana przez cesarza w roku 1910 pozwolita w latach 1910-1915 rozszerzyć granice miasta. W 1915 roku, przypadającym już na okres wojny po przyłączeniu Podgórza, powierzchnia miasta wynosiła 4690 ha.

21 J. M. Małecki, Życie gospodarcze..., dz. cyt., s. 53. Powierzchnia miasta w latach 1909-1912 wzrosła siedmiokrotnie.

22 J. Bieniarzówna, J. M. Małecki, Dzieje Kraków..., dz. cyt., s. 358. Nowa linia forteczna biegła od Kopca Kościuszki do koszar w Lobzowie, a dalej ciągnęła się wzdłuż linii kolejowej.

${ }^{23}$ Tamże, s. 358. Ograniczenia wojskowe powodowaty ,zastój” miasta. W Krakowie obowiązywał bowiem zakaz wznoszenia wszelkich wyższych budynków oraz tzw. rewersy demolacyjne poza linią wałów fortecznych.

${ }^{24}$ Tamże, s. 378; J. M. Małecki, Życie.., dz. cyt., s. 54. Fabryki były usytuowane zarówno w obrębie miasta, np. fabryka papierosów jak i na przedmieściach. Niektóre, takie jak Fabryka sodu Bernarda Libana w Borku Fałęckim, znajdowały się poza granicami administracyjnymi przez wiele lat.

is Towarzystwo Wzajemnych Ubezpieczeń - „Florianka” miało siedzibę w obecnym gmachu Zespołu szkół Muzycznych oraz Auli Akademii Muzycznej - przyp. aut.

${ }^{26}$ J. M. Malecki, Życie.., dz. cyt., s. 54 . 
dał wodociagi ${ }^{27}$, co pozwoliło Radzie Miasta usprawnić kanalizację miejską. Pod koniec XIX wieku miasto uruchomiło elektrownię miejską w Podgórzu ${ }^{28}$. Przeprowadzono też na większą skalę uporządkowanie miasta (m.in. regulacja sieci rzecznej) $)^{29}$, poprawiono wygląd miasta poprzez renowację domów mieszkalnych, zagospodarowanie Plant czy też likwidację błotnistych ulic w mieście na rzecz płyt chodnikowych $^{30}$. Kraków utworzył także krakowską sieć telefoniczną, która już w 1906 roku posiadała własną centralę ${ }^{31}$.

Rozbudowa Krakowa, a także wzrost liczby mieszkańców doprowadził także do stworzenia komunikacji miejskiej. Już w roku 1875 Kraków posiadał pierwsze omnibusy konne. Przedsięwzięcie to z początku okazało się nierentowne, stąd zrezygnowano $z$ niego po krótkim czasie. Siedem lat później Kraków otworzył pierwszą linię tramwaju konnego (trasa dworzec kolejowy - most Podgórski). Pomimo tego dopiero w kilkanaście lat później prawdziwa modernizacja Krakowskiej Spółki Tramwajowej i elektryfikacja linii doprowadziła do otwarcia kolei elektrycznej ${ }^{32}$.

Dzięki przemianom kulturowym na początku XX wieku Kraków stał się duchową stolicą Polski. Choć państwo nie istniało już od ponad wieku, to jednak duch narodu przetrwał. W obrębie kultury zaszły wtedy poważne zmiany. Miasto było siedzibą najważniejszych ośrodków naukowych, tj. Uniwersytetu Jagiellońskiego, Akademii Sztuk Pięknych oraz Akademii Umiejętności. Zarówno szkoły jak i uczelnie krakowskie ściągały do siebie rzesze młodych ludzi z całej Polski. Ogromny wpływ na Kraków miał okres Młodej Polski, dzięki któremu przeobraził się on w centralny ośrodek polskiej nauki, sztuki oraz literatury. To w tym mieście powstawały jedne $\mathrm{z}$ najważniejszych dzieł tej epoki ${ }^{33}$.

Poprzez przemiany w dziedzinie gospodarki jak i prądy modernistyczne charakter Krakowa zmieniał się diametralnie. Choć liczba polemik, wystąpień politycznych wzrosła i w latach przed wojennych przybrała bardziej ostry charakter, to jednak nie zmieniło to tolerancyjnego nastawienia wobec innych narodów ${ }^{34}$. Praw-

${ }^{27}$ J. Bieniarzówna, J. M. Małecki, Dzieje Kraków..., dz. cyt., s. 349. Była to jedna z najpotrzebniejszych modernizacji w mieście. Doprowadzenie świeżej wody dla mieszkańców wiązało się ze spadkiem zachorowań na choroby zakażne oraz $z$ utrzymaniem higieny $w$ mieście. $W$ przeciwienstwie do innych miast Polski Kraków dopiero w 1901 posiadał własne wodociągi.

${ }^{28}$ Tamże, s. 351. Elektrownia powstała w 1908 roku. Potrzeba budowy zaistniała już we wcześniejszym okresie. Jednak duża konkurencja ze strony Gazowni Miejskiej utrudniała jej powstanie. Dla przykładu dopiero w 1912 roku uchwalono zmianę gazowego oświetlenia ulic na elektryczne.

29 Tamże, s. 347. Przeprowadzenie regulacji Wisły było jednym z istotnych zmian, jakie zaprowadzono w mieście. Ułatwiło to w dużej mierze życie mieszkańcom i zabezpieczyło przed klęskami powodzi.

${ }^{30}$ Tamże, s. 350. Na przykładzie innych miast Monarchii Kraków posiadał także Zakład Czyszczenia Miasta, jednakowoż nie poprawiło to wizerunku Krakowa, który nadal pozostawał miastem zaśmieconym.

${ }^{31}$ Tamże, s. 354.

${ }^{32}$ J. Bieniarzówna, J. Małecki, Dzieje Kraków..., dz. cyt., s. 352. Na początku I wojny światowej funkcjonowało 6 linii tramwajowych. W ramach rozbudowy komunikacji miejskiej, na krótko przed wybuchem wojny, starano się utworzyć komunikację autobusową.

${ }^{33}$ Tamże, s. $364-377$. Do Krakowa przyjeżdżali tacy wielcy twórcy jak Leopold Staff, Stefan Żeromski, Jan Kasprowicz, Stanisław Przybyszewski.

${ }^{34}$ Tamże, s. 379. 
dopodobnie kluczową rolę w rozwoju myśli i działań patriotycznych odegrał ustrój i polityka państwa habsburskiego. Wprawdzie sami Polacy nie mieli szans na utworzenie samodzielnego państwa z części ziem polskich, jakie wchodziły w obręb monarchii, to polityka Habsburgów wobec polskiej narodowości w porównaniu $\mathrm{z}$ innymi zaborcami była liberalna. Polityka taka wynikała przede wszystkim $\mathrm{z}$ interesów mocarstwowych Austro-Węgier. Państwo nastawione było na udzielanie mniejszościom narodowym szerokiej autonomii, co miało osłabiać ich starania odśrodkowe ${ }^{35}$.

W samym Krakowie przed wybuchem wojny istniał rozwinięty system obozów politycznych, zwłaszcza że w zaborze austriackim partie polityczne działały legalnie ${ }^{36}$. Co do samych stronnictw politycznych, to osłabła rola stańczyków. Młodzi konserwatyści nadal jednak odgrywali znaczącą rolę. Taką też rolę zyskały stronnictwa burżuazyjne, przede wszystkim Stronnictwo Demokratyczne. Ostatnie przed wojną wybory do Rady Miejskiej odbyły się w maju 1914 roku, zostały przeprowadzone według starej ordynacji wyborczej, stąd nie były one odzwierciedleniem politycznych poglądów ogółu krakowskiego społeczeństwa ${ }^{37}$.

\section{SY̌LWETKA BISKUPA KRAKOWSKIEGO ADAMA STEFANA SAPIEHY}

Kościół katolicki od wieków był wpisany w życie Krakowa i w przededniu wojny nadal posiadał ogromne wpływy. W 1911 roku umarł kardynał Jan Puzyna ${ }^{38}$, a na jego miejsce papież Pius X konfirmował młodego księcia Adama Stefana Sapiehę ${ }^{39}$.

Adam Stefan Sapieha pochodził podobnie jak kardynał Puzyna z rodziny arystokratycznej. Urodził się $14 \mathrm{~V} 1867$ roku w Krasiczynie ${ }^{40}$. Był siódmym dzieckiem Jadwigi z Sanguszków i Adama Sapiehy zwanego „czerwonym księciem”. Linia Sapiehów wyróżniała się na tle innych środowisk arystokratycznych swoim patriotyzmem i tradycją społecznikowską ${ }^{41}$. Rodzina była bardzo zamożna, stąd

${ }^{35}$ J. Holzer, J. Molenda, Polska ..., dz. cyt., s. 27.

${ }^{36}$ Tamże, s. 35. Stronnictwa pracowały przy sejmie galicyjskim jak i parlamencie wiedeńskim.

${ }^{37}$ J. Bieniarzówna, J. Małecki, Dzieje Krakowa..., dz. cyt., s. 381 . Autorzy podają, że wraz z wybuchem wojny w skład Rady wchodziło 87 członków. Ponad $2 / 3$ ich stanowiło przedstawicielstwo inteligencji. Natomiast pod względem przynależności partyjnej 43 należało do stronnictwa mieszczańskiego, 27 do stronnictwa demokratycznego, 10 konserwatystów, a reszta to posłowie niezależni.

${ }^{38}$ zob. J. Kracik, Jan Puzyna, PSB XXIX, s. $488-491$.

${ }^{39}$ zob. J. Wolny, Adam Stefan Sapieha, PSB XXXIV, s. 539-557; Księga Sapiezyńska, t. 1-2, pod red. J. Wolnego, Kraków 1982; M. Rożek, Kardynat Sapieha, Kraków 2007; B. Przybyszewski, Adam Stefan Kardynal Sapieha, Lańcut 2000.

${ }^{40}$ Z. Wilgu sz, Kronika życia i dzialalności Adama Stefana Kardynala Księcia Sapiehy, [w:] Kardınal Adam Stefan Sapieha, środowisko rodzinne, życie i dzieto, Przemyśl 1995, s. 203. 19 maja zostal ochrzczony jako Adam, Stefan, Stanisław, Bonifacy, Józef.

${ }^{41}$ S. Kieniewicz, Srodowisko rodzinne Adama Stefana Sapiehy, [w:] Ksiegga Sapieżyíska, pod red. J. Wolnego, Kraków 1982, t. 1, s. 23. Ojciec Adama - Adam był propagatorem akcji pomocy dla powstania 
dzieciom w dzieciństwie i młodości niczego nie brakowało (choć tradycją w rodzinie było nie żyć „ponad stan”). Ojciec Adama, Adam Stanisław Sapieha był człowiekiem, który w swoim środowisku wyróżniał się nieugiętą postawą patriotyczną oraz nieustępliwością wobec zaborców. Był oddany sprawie Ojczyzny, czego dowodem było organizowanie akcji pomocy dla powstania styczniowego we Lwowie. Za tą działalność został ukarany przez władze austriackie więzieniem. Natomiast dziadek Leon Sapieha był wieloletnim marszałkiem krajowym, którego życiową dewizą była praca dla kraju. Dla wnuków był wzorem postawy pełnego poświęcenia i oddania Ojczyźnie. Zarówno ojciec jak i dziadek Adama pomimo patriotycznej postawy i aktywności na gruncie spolecznym nie zostali przywódcami wśród mieszkańców części Galicji, którą zamieszkiwali. Problemem stała się nieufność wobec „czerwonych”. Stąd środowisko, w jakim się wychowywał Adam, było wyizolowane od arystokracji, która podchodziła doń z sarkazmem i niechęcią ${ }^{42}$. Matka Adama Stefana, Jadwiga z Sanguszków była kobietą cichą i powściągliwą. Poprzez swoją łagodność potrafiła wpływać na męża, zwłaszcza na jego często dość szalone plany. Dzięki swojemu spokojowi i opanowaniu udało jej się wybaczać romanse, jakich „dostarczał" jej współmałżonek. Wierzyła, że te „historie" nie są w stanie rozbić czy też zachwiać instytucji, jaką była rodzina ${ }^{43}$. Jeszcze jedną z osób, wśród których dorastał młody Adam, była jego babka Jadwiga z Zamoyskich. Kobieta ta odznaczała się do późnych swych lat ogromną energią, którą to przekładała na pomoc dla najuboższych. Przykładem jej chrześcijańskiej miłości był przede wszystkim patronat nad znaczną liczbą instytucji charytatywnych we Lwowie ${ }^{44}$.

Dla młodego Adama największym autorytetem był ojciec. Adam Sapieha był dla swych dzieci przyjacielem, poświęcał im wiele czasu, a w chwilach, gdy był pochłonięty polityką, utrzymywał z nimi korespondencję, w której przesyłał liczne rady dotyczące ich życia. Będąc 11-letnim chłopcem Adam Stefan wyruszył w podróż do Rzymu razem $z$ rodzicami. Został tam przedstawiony ówczesnemu papieżowi Leonowi XIII, który to wcześniej będąc jeszcze kardynałem (Joachim Pecci), nawiązał przyjacielskie kontakty $\mathrm{z}$ ojcem Adama ${ }^{45}$.

Naukę Adam Stefan rozpoczął w Krasiczynie, gdzie uczyli go domowi nauczyciele. Pierwszą szkołą było IV Wyższe Gimnazjum we Lwowie, które zakończył w 1886 roku egzaminem dojrzałości. Okres gimnazjalny był bardzo istotny w jego życiu. Duży wpływ na niego miały idee patriotyczne, które mógł rozwijać

\footnotetext{
styczniowego we Lwowie. Za co został ukarany przez władze austriackie więzieniem. Zarówno ojciec jak i dziadek Adama, pomimo patriotycznej postawy i aktywności na gruncie społecznym nie zostali przywódcami wśród mieszkańców ich rejonu. Problemem byla nieufność wobec „czerwonych”. Stąd środowisko, w jakim się wychował Adam było wyizolowane od arystokracji, która podchodziła doń z sarkazmem i niechęcią.

${ }^{42} \mathrm{~S}$. Kieniewicz, Srodowisko rodzinne..., dz. cyt., s. 27.

${ }^{43}$ Tamże, s. 26-27.

${ }^{44}$ Tamże, s. 26.

${ }^{45}$ J. Wolny, Modość i pierwsze lata dzialalności Adama Stefana Sapiehy, [w:] Księga Sapieżyńska,
} t. 1, Kraków 1982, s. 33. 
poprzez atmosferę domu jak i obserwację działalności ojca. W wieku 19 lat młody książę przygotowywał się do rozpoznania swojej drogi życiowej.

W roku 1886 dostał się na Wydział Prawa Uniwersytetu Jagiellońskiego. Jednakże nie podjął tam studiów. Rozpoczął natomiast studia na Uniwersytecie Wiedeńskim $^{46}$. Prawdopodobnie ojciec młodego księcia, posyłając go na studia do Wiednia, pragnął przybliżyć mu arkana polityki europejskiej, zwłaszcza habsburskiej. Po skończeniu studiów prawniczych Adam Sapieha uczestniczył w wykładach $w$ Lille $w$ Institut Catholique. Absolutorium $z$ prawa $w$ Wiedniu otrzymał w 1892 roku $^{47}$. W 1890 roku zapisał się na Wydział Teologiczny Uniwersytetu w Innsbrucku. Prawdopodobnie w tamtym okresie postanowił zostać duchownym. Nie bez znaczenia był zamysł rodziców co do kariery duchownej najmłodszego syna. Sama rodzina była bardzo religijna i katolicka, co było ogromnym przykładem dla księcia Adama ${ }^{48}$. Studia zakończył w roku 1894; w trakcie ich trwania został wpisany na trzeci rok alumnów studiów seminaryjnych. Zarówno święcenia diakonatu jak i kapłaństwa otrzymał w 1893 roku z rąk biskupa Puzyny. Mszę św. prymicyjną odprawił w kaplicy pałacu we Lwowie, następnie w Krasiczynie ${ }^{49}$.

W roku 1894 został wysłany przez arcybiskupa lwowskiego S. Morawskiego do parafii Jazłowiec koło Buczacza na stanowisko wikarego. Początkowo parafianie nie darzyli sympatią nowo przybyłego wikarego, jednak z czasem, dzięki jego działalności w parafii potrafili przekonać się do jego zalet - między innymi dzięki ofiarnej postawie Sapiehy przy niesieniu pomocy chorym w okresie epidemii ${ }^{50}$. Już w roku 1895 wyjechał na studia do Rzymu ${ }^{51}$. W 1896 roku podjął studia doktoranckie $\mathrm{z}$ dziedziny prawa w Pontificia Accademia Ecclesistica oraz studia dyplomatyczne w Accademia Dei Nobili Ecclesiastici. W Rzymie był określany jako rzecznik spraw polskich w Stolicy Apostolskiej. Na taką opinię wpływała bliska znajomość Sapiehy z przedstawicielami Kurii Rzymskiej jak i znajomość z ówczesnym papieżem Leonem XIII. Jednak po studiach musiał wracać do archidiecezji lwowskiej ${ }^{52}$. W ciągu kolejnych 9 lat mianowany był na urząd wicerektora Seminarium Metropolitalnego we Lwowie, sekretarza sądu diecezjalnego i metropolitalnego, egzaminatora prosynodalnego. Otrzymał także kanonikat kapituły metropolitalnej ${ }^{53}$.

$\mathrm{Na}$ rok 1899 przypada ważne wydarzenie dla rodziny Sapiehów - upadek lwowskiego Banku Kredytowego. Likwidacja Banku dotknęła bardzo poważnie ro-

${ }^{46}$ Tamże, s.35. Na wydziale prawa Uniwersytetu Jagiellońskiego studiował na drugim roku.

${ }^{47}$ J. Wolny, Adam Stefan Sapieha, PSB, s. 539.

${ }^{48}$ S. Kieniewicz, tamże, s. 28.

${ }^{49}$ J. Wolny, Modość.., dz. cyt., s. 36.

${ }^{50}$ Tamże, s. 37.

${ }^{51}$ Tamże, s. 39; J. Wolny, Adam Stefan Sapieha, dz. cyt., s. 540. Przed studiami wyjechał w celu głoszenia misji rekolekcji parafialnych na Górny Śląsk.

${ }_{52}$ J. Wolny, Modość..., dz. cyt., s. 39. W trakcie powrotu do Lwowa zatrzymał się w Bośni, gdzie wykazywał zainteresowanie tamtejszą polską emigracją i jej problemami.

${ }_{53}$ Tamże, s. 42. W roku 1901 wyjechał na kilka miesięcy do Stanów Zjednoczonych z powodów rodzinnych. 
dzinę Sapiehów, gdyż ta musiała spłacać ogromną ilość wierzycieli. Wielkim gestem młodego Adama było wówczas przekazanie bankowi w celu ratowania honoru rodziny całej swojej fortuny ${ }^{54}$.

Zwycięstwo Japonii $\mathrm{w}$ wojnie japońsko-rosyjskiej pośrednio spowodowało wzrost dążeń Polaków do niepodległości w zaborze rosyjskim. W tym trudnym czasie powstał list papieża Piusa X (1905) Poloniae populum mówiący o zachowaniu pokoju i zachowaniu szacunku wobec władzy ${ }^{55}$. Wystąpienie papieża spowodowało masę wystąpień antypapieskich $w$ Królestwie. Sprawę wyjaśnienia słów papieża podjął arcybiskup lwowski o. orm. Józef Teodorowicz ${ }^{56}$. W tym czasie zrodziła się myśl powołania księdza Adama do otoczenia papieża, który zajmowałby się przekazywaniem spraw dotyczących Polski. W takiej sytuacji abp Teodorowicz przedstawił Papieżowi Piusowi X Adama Stefana Sapiehę. Na początku roku 1906 Adam Sapieha został powołany do Watykanu jako camerie segreto patricipante della Sua Santità. Jego przygotowanie merytoryczne było odpowiednie dla tej misji ${ }^{57}$. Po drodze do Watykanu Sapieha zatrzymał się w Wielkopolsce, by tam nawiązać liczne kontakty między innymi w celu pozyskania informacji na temat poczynań pruskiej władzy wobec Kościoła polskiego na tamtych ziemiach.

Należy zauważyć, że w Watykanie już wcześniej działali Polacy, m.in. takie osobistości jak kard. Mieczysław Ledóchowski. Jednak wszyscy oni działali w interesie wyłącznie swoich zaborów. Powołanie Sapiehy miało doprowadzać do uniknięcia podawania sprzecznych i niespójnych, często wykluczających się informacji. Okres działalności Sapiehy w Watykanie był bardzo ważny i dynamiczny dla sprawy polskiej. Do jego najważniejszych interwencji możemy zaliczyć przygotowanie listy godnych zaufania duchownych jako przyszłych biskupów w Rosji czy też przedstawianie memoriałów w sprawie strajków szkolnych dzieci polskich w zaborze pruskim ${ }^{58}$.

Przełomowy moment dla Sapiehy nastąpił w 1911 roku, kiedy po śmierci kardynała Puzyny zaproponowano jego kandydaturę na biskupstwo krakowskie. Początkowo Krakowska Kapituła Katedralna jak i cały Kościół krakowski liczyli na wybór dotychczasowego biskupa pomocniczego Anatola Nowaka ${ }^{59}$. Większość biskupów galicyjskich opowiadała się za wyborem bp. Nowaka, jednakże oprócz tej kandydatury episkopat galicyjski wysunął kolejno: bp. pomocniczego lwowskiego

${ }^{54}$ Tamże, s. 29. Było to pół miliona złotych reńskich.

${ }^{55}$ J. Wolny, Mlodość., dz. cyt., s. 55. List był skierowany do biskupów polskich znajdujących się z zaborze rosyjskim. Papież przypominał im także o trosce o duchowieństwo jak i uczenia młodzieży religii.

${ }^{56}$ Tamże, s. 56. Komentarz do słów papieża znalazł się w „Przeglądzie Powszechnym”.

${ }^{57}$ Tamże, s. 57. Informację o tym posunięciu Piusa $X$ otrzymali wszyscy biskupi galicyjscy.

${ }^{58}$ J. Wolny, Adam Stefon Sapieha, PSB, s. 540-541. W sprawie strajków w zaborze pruskim nie było jednoznacznej reakcji ze strony Watykanu. Jakkolwiek sam papież wielokrotnie dawał wyraz przychylnemu nastawieniu wobec strajków.

${ }^{59}$ B. Kumor, Powotanie Adama Stefana Sapiehy na biskupstwo krakowskie, [w:] Księga Sapieżyńska, t. 1, Kraków 1982. Biskup pomocniczy Anatol Nowak pod koniec rządów schorowanego kardynała Puzyny de facto sprawował władz̨̨ w diecezji. 
Władysława Bandurskiego, bp. przemyskiego Józefa Pelczara, ks. Stefana hr. Komorowskiego oraz ks. Adama hr. Potulickiego. Swoją obecność na liście ks. Adam Stefan Sapieha zawdzięczał prawdopodobnie biskupowi Wałędze ${ }^{60}$. Za kandydaturą Sapiehy opowiedzieli się konserwatyści galicyjscy i kandydaturę tę popart ówczesny namiestnik Michał Bobrzyński. W swoich pamiętnikach tak opisał to wydarzenie: „(...) [Kandydaturze Sapiehy] był arcybiskup [Bilczewski] przeciwny, wolał bowiem na stolicy krakowskiej widzieć ks. Anatola Nowaka, biskupa sufragana, i uległ dopiero mojej perswazji, gdym mu przedstawił, iż jest rzeczą pożyteczną, ażeby także arystokracja polska miała w episkopacie galicyjskim swojego przedstawiciela (...)"61. Kandydatura Sapiehy została jednogłośnie przyjęta 31 X 1911 roku podczas obrad Rady Państwa. Dnia 8 XI 1911 roku Cesarz Franciszek Józef mianował go biskupem ordynariuszem krakowskim ${ }^{62}$. Następnie 27 XI nastąpiła prekonizacja papieska. Sakrę biskupią otrzymał w dniu 17 XII 1911 roku z rąk Piusa $\mathrm{X}$ w bazylice św. Piotra na Watykanie ${ }^{63}$.

Nowo wybrany biskup przyjechał do Krakowa dnia 1 III 1912 roku $^{64}$. Ingres odbył się 3 III w katedrze na Wawelu. Sapieha w dniu ingresu wydał dwa listy: $D o$ wiemych i Do duchowieństwa. W liście do wiernych przypomniał o obowiązku podtrzymania i szerzenia wiary, o znaczeniu wielkiej roli rodziny, poruszał także

${ }^{60}$ Tamże, s. 171 .

${ }^{61}$ M. Bobrzyński, Z moich pamiętników, Wrocław 1957, s. 370-371; por. J. Kumor, tamże, s. 171-172. Jakkolwiek w samym wniosku Ministerstwa WRiOP abp Bilczewski wypowiadał się na temat Sapiehy przychylnie wskazując go jako gorliwego i oddanego pracy kapłana ; por. J. Wołczański, Adam Stefan Sapieha w korespondencji z biskupami Galicji (matopolski) w latach 1900-1939, [w:] Kardynat Adam Stefan Sapieha- środowisko rodzinne, życie i dzieło, Przemyśl, s. 117.

${ }^{62}$ B. Kumor, tamże, s. 173. We wniosku przedłożonym cesarzowi Sapieha był przedstawiany jako jedyny kandydat na Kraków; por. AKKK, b. sygnatury, List namiestnika do kapituły krakowskiej zawiadamiający o nominacji cesarskiej: „Do Przewielebnej Kapituły katedralnej w Krakowie. Jego Ces. I Król. Apostolska Mość Najwyższem postanowieniem z dnia 8. Listopada b. r. raczył najmiłościwiej zamianować kanonika rz. Kat. Kapituły metropolitalnej we Lwowie księcia Adama Sapiehę, księciem biskupem krakowskim. Oczem mam zaszczyt zawiadomić Przewielebną Kapitułę katedralną. W skutek reskryptu Jego Ekscelencji. Pana Ministra wyznań $i$ oświaty z dnia 24 XI 1911".

${ }^{63}$ J. Kumor, tamże, s. 173.

${ }^{64}$ Archiwum Kurii Metropolitalnej w Krakowie (dalej AKMK), Liber actionum Celsissimi Ordinarii Cracoviensis Adami Stephani Sapieha Principis Episcopi, z dnia 1 marca 1912 roku. W życiorysie prowadzonym przez kapelana Sapiehy ks. dr Józefa Niemczyńskiego znajdziemy szczególowy opis tego dnia: „(..) dnia 1 marca 1912 wyjechał książę biskup z Krasiczyna do Krakowa na stały pobyt. Dzień ten byl bardzo piękny słońce ślicznie świeciło wiosnę czuć było w powietrzu. Na stacji w Krakowie o godzinie 2 minut 20 zebrały się wszystkie władze krakowskie z prezydentem na czele z panem Leo, który w sali królewskiej pięknie ubranej kwiatami przywitał księcia biskupa tymi słowy. (...) Potem przedstawiali się księciu biskupowi wszyscy $z$ władz tam zebrani. W powozie zaprzężonym w białe arabki w prezencie od ks. Sanguszki (...) przyjechał książę biskup wśród szpaleru utworzonego przez młodzież gimnazjalną ze swoimi muzykami ,przez wojsko ,przez thumy publiczności wśród salw dobiegających ze strzelnicy do kościoła Panny Marii gdzie od Wielkiego Ołtarza przemówił do ludu i po raz pierwszy udzielił błogosławieństwa (...)"; por. Archiwum Uniwersytetu Jagiellońskiego (dalej: AUJ), S II 548: Akta i korespondencja Senatu UJ z przedstawicielami Kościola katolickiego oraz innych wyznań 1851-1934; wysyłano do przedstawicieli różnych stanów $w$ tym do profesorów Uniwersytetu Jagiellońskiego informacje o przyjeździe biskupa Adama Sapiehy i zaproszenie na odbywającą się z tej okazji uroczystość. 
kwestię społeczną (nawiązywał do encykliki Rerum Novarum) ${ }^{65}$. Wspomniał też o powinnościach wiernych względem Ojczyzny ${ }^{66}$.

Swoją wizję współpracy $\mathrm{z}$ duchowieństwem jak i samego kapłaństwa przedstawił $\mathrm{w}$ drugim ze wspomnianych listów. Wymagał od kapłanów poświecenia $\mathrm{w}$ pracy wobec bliźnich (Ora, labora et ama). Według niego to oni mieli poprzez dobre przygotowanie skutecznie głosić Ewangelię wiernym. Uważał, że życie kapłanów to przede wszystkim wzorowy przykład pobożności, modlitwy oraz dobroci serca wobec najbiedniejszych. Wobec kapłanów zwłaszcza kleryków Sapieha kierował się troską i ojcowską milością ${ }^{67}$.

Objęcie metropolii krakowskiej przez Sapiehę nie spotkało się z radosnym przyjęciem ze strony duchowieństwa zakorzenionego w konserwatyzmie poprzednika. Między innymi apelowano do niego o nie wprowadzanie żadnych zmian w diecezji. Okres po objęciu biskupstwa wspominał następująco:

„Pierwsze dwa lata przedwojenne przeszły w stosunkach ułożonych wedle systemu austriackiego $\mathrm{w}$ tradycjach wyrobionych przez poprzednika kard. Puzynę. Były one dla mnie czasem rozglądania się w stosunkach i rozpoznawania ludzi ale też $w$ prawdzie cichej nie mniej jednak intensywnej walki tak $z$ tradycjami a szczególnie $\mathrm{z}$ ludźmi dawnego systemu i to nie tylko w polityce lecz także $\mathrm{w}$ samej diecezji".

Z Rzymu przybyłem zostawiając tam jak najlepsze relacje. Papieża łaskawie usposobionego i pewien serdeczny stosunek w Watykanie gdzie wracając dwa razy spotkałem prawie rodzinne stosunki niezmiernie miłe. Na kierunek w ważniejszych sprawach nie mogło to mieć wielkiego wpływu jednak czułem się tam zawsze jak najlepiej przyjęty $i$ widocznie miano zaufanie do mnie choć nie zawsze robiono to co przedstawiałem będąc $w$ rozmaitych sprawach zapytywany. Te koneksje i częste wypowiedzenie się Ojca św. bardzo łaskawe powodowały że mimo iż nie byłem sympatycznie przyjęty w Krakowie jednak obawiano się otwarcie występować i tylko tajemnie robota szła.

${ }^{65}$ B. Przybyszewski, Adam Stefan kardynal Sapieha. Pasterz dobry - ksiqżę niezlomny, Lańcut 2000, s.74. W przeciwieństwic do swego poprzednika kardynala Puzyny, Sapieha dostrzegał potrzebę uporządkowania kwestii socjalnej. Według jego zamysłı Kościół miał zaopiekować się robotnikami. Sam dawał przykład w dawaniu pomocy robotnikom, poprzez układanie wzajemnych stosunków pomiędzy nimi, a pracodawcami, które w dużej mierze opierały by się na chrześcijańskiej miłości. Założył także Stowarzyszenie Robotników Katolickich (1914). Co przyczyniło się do powstania 30 Chrześcijańskich Związków Zawodowych w diecezji krakowskiej.

${ }^{66}$ A. Bacińs ki, Dzialalność charytatywna Adama Stefana Sapiehy do roku 1918, [w:] Ksiega Sapieżyńska, dz. cyt., s. 265-267. Fragment kazania ingresowego: „(...) Aby shuźyć Ojczyźnie, trzeba prawdy w życiu, trzeba ofiary z siebie, trzeba pracy wielkiej, żmudnej, często nie wynagrodzonej ni chwałą, ni imieniem, ni stanowiskiem. Bez tego ognia wewnętrznego, bez tego światła nadprzyrodzonego, jakże latwo zasklepi się serce nasze i zamiast szukać dobra ogółu będzie siać niezgodę i walkę domową w imię ciasnych rzekomo interesów, a co gorsze ześliźnie się tak nisko, iż własny interes, prywatę postawi sobie za cel pracy i zabiegów(...)".

${ }^{67}$ B. Przybyszewski, tamże, s. 71-72. 
„Zastałem diecezję w stanie wewnętrznym dobrze zorganizowanym pod twardą ręką Kardynała. Długoletnia jego choroba jednak wytworzyła obok niego rządy poboczne zasłaniające się postrachem jego bardzo niechętne nowemu przybyszowi. Od chwili konsekracji a tem bardziej przyjazdu do Krakowa chciano mi narzucić dawny system opierający się głownie o pewne osoby jak o teoretyczny poglądy bo te były tylko potrzebne by osoby miały pewien stan posiadania. Ruszenie którejkolwiek $z$ osób było uważane za herezję. Przeciwstawiano się nie gwałtownie ale cichcem. Paladium całej tej koterii było seminarium w którem upatrywano szczyt doskonałości (...).

Tak w diecezji jak i Seminarium dostrzegłem zaraz że system ten zabiłby zupełnie życie i rozwój. Błędem moim było że nie umiem i nie lubię gwałtownie z pewnym tak powiem fizycznym naciskiem wywołującym strach działać. To też kierunek ten wprawdzie nie zwyciężył ale też ukryty działał dalej szerząc niezadowolenie i krytykę. Rozpuszczano że niedługo będę w diecezji byle tylko nie dać upaść swemu znaczeniu. Zmiany w seminarium a także na ważniejszych posterunkach w diecezji choć bardzo krytykowane jednak przeszły dość gładko choć ta podziemna akcja nie dozwoliła uskutecznienia dobrego wpływu zmian (...)

System poprzedni miał to do siebie że zniszczył indywidualność wszystkich pograzżał w pewien sen $i$ bierność którą pokrywano świetnymi frazesami. To też dziesięć lat walczę z brakiem zupełnym ludzi na stanowisko trochę odpowiedzialniejsze. Najbardziej odczuwa się to przy rektoracie seminarium. Zmieniłem już 4 rektorów a nie mogę odpowiedniego znaleźćc68.

Biskup Sapieha w czasie swojego ingresu podjął uroczystym obiadem najuboższych w dwóch miejscach: w domu ss. miłosierdzia na Kazimierzu, a także u ss. szarytek na ulicy Piekarskiej ${ }^{69}$. Ten gest był zapowiedzią działań, jakimi objął w późniejszych latach swojego pasterzowania ludzi najuboższych i poszkodowanych. Dlatego już w 1913 roku założył Komitety parafialne, które miały rozszerzyć dzieło pomocy nad najuboższymi w diecezji krakowskiej ${ }^{70}$. Zachęcał wiemych, by w duchu chrześcijańskiej miłości zakładano ochronki dla dzieci, instytucje które by się zajmowały opieką nad sierotami i chorymi.

\section{WYBUCH WOJNY I JEJ NASTEPSTWA DLA KRAKOWA I OKOLIC}

Zabójstwo następcy tronu arcyksięcia Franciszka Ferdynanda 28 VI 1914 roku zaniepokoiło opinię międzynarodową. Wydarzenia potoczyły się dość szybko

\footnotetext{
${ }^{68}$ Archiwum Kapituły Katedralnej w Krakowie (dalej AKKK), b. sygn, Dziesięć lat po ingresie; por. J. Urban, Pierwsze lata posiugi Księcia Adama Stefana Sapiehy w diecezji krakowskiej, [w:] Charisteria Tito Górski oblata, Kraków 2003.

${ }^{69}$ AKMK, Liber.., $\mathrm{z}$ dnia 3 marca 1912 roku.

${ }^{-0}$ A. Baciński, Dzialalność..., dz. cyt., s. 266; por. A. Vetulani, Arcypasterz krakowski na przelomie epok .[u:] Kościól w II Rzeczpospolitej, Lublin 1981, s. 107.
} 
i już w sierpniu Kraków znalazł się blisko frontu, co spowodowało jego realne zagrożenie ze strony działań wojennych. Dnia 30 VII 1914 w dziennikach galicyjskich pojawił się Manifest do ludów a w kilka dni później podano Obwieszczenie ogólnej mobilizacji gdzie powoływano pospolite ruszenie monarchii austrowęgierskiej $^{71}$.

Mobilizacja przebiegała wedhug wcześniej przygotowanego planu. Oficerowie, którzy przebywali w rezerwie zawiadamiani byli osobiście, natomiast powołaniem szeregowców zajmowali się wójtowie w gminach. Władze wojskowe w Galicji zaskoczyła ilość zgłoszeń i żarliwość, z jaką ludność zgłaszała się do punktów werbunkowych ${ }^{72}$. W swojej pracy Juliusz Bator przywoływał opis pierwszych dni w Krakowie pozostawionych przez historyka Jana Dąbrowskiego:

„Kraków 19 VIII(...)Nastrój ludności mamy również dobry. Wszyscy idą przeciw Rosji. O żadnym słowianofilstwie nikomu się nawet nie śni. Wojsko spokojne; przez Kraków przewinęło się go tysiące, a nigdzie nie widziałem, już nie nadużyć, lecz nawet pijanego żołnierza (...) Wszyscy wierzą święcie, że Rosja musi być pobita $(. . .)^{73}$ ".

W kilka dni później (9 VIII) została wydana odezwa Naczelnej Komendy Wojsk austrowęgierskich Do narodu polskiego ${ }^{74}$. Przedstawiała sprzymierzone armie jako wyzwolicieli „spod jarzma moskiewskiego”. Nawiązywała ona w sposób szczególny do zaboru austriackiego: „Powitajcie nasze sztandary z ufnością, bo one zapewniają Wam sprawiedliwość. Sztandary te nie są Wam i Waszym rodakom obce. Wszakże przez półtora przeszło wieku rozwija się wspaniale Wasz naród pod berłem Austrji-Węgier i Niemiec i pełne sławy tradycje Waszej przeszłości łączą się jak najściślej jeszcze od czasów króla Jana Sobieskiego, który pośpieszył ze skuteczną pomocą zagrożonemu państwu Habsburgów, z tradycjami Waszych sąsiadów na zachodzie". Powołując się na przymioty narodu polskiego, mówili o swoim planie: „Chcemy usunąć te zapory, jakie utrudniały Wam ściślejszą łączność z życiem Zachodu, chcemy otworzyć przed Wami wszystkie skarby duchowego i gospodarczego dorobku...". Na koniec przedstawiali powody dla, których państwa centralne zostały zmuszone do wojny (winą obarczając Rosję) oraz apelując do Polaków: ,(...) zawierzcie ochotnie i z pełną ufnością naszej opiece, poprzyjcie nasze usiłowania $\mathrm{z}$ całego serca (...)"75.

Również wcześniej wspomniane polskie oddziały paramilitarne stacjonujące w Galicji z początkiem sierpnia oddały się pod komendę Józefa Piłsudskiego. Pla-

\footnotetext{
${ }^{7}$ Manifest do ludów, „Głos Narodu” R: XXII(1914), nr 171, s. 1; Obwieszczenie mobilizacji, „Głos Narodu" R: XXII (1914), nr 174, s. 1.

72 J. Bator, Wojna galicyjska, Kraków 2005, s. 40. Autor podaje że powołani mieli na stawienie się do określonych punktów 48 godzin, większość pojawiła się już po 10 godzinach.

${ }^{73}$ Tamże, s. 41.

${ }^{74}$ Manifest armii austriackiej do Narodu Polskiego w Królestwie, „Głos Narodu” R: XXII (1914), nr 183, s.1

${ }^{75}$ Tamże.
} 
nowane ze strony polskiej wysłanie oddziałów strzeleckich było pertraktowane z Wiedniem. Stąd na początku sierpnia austriackie władze wojskowe wyraziły zgodę na powstanie przy austriackiej armii polskich oddziałów strzeleckich. Do 6 VIII 1914 roku powstała I kompania kadrowa, której trzon stanowiły drużyny „strzelców". Głównym celem tej organizacji miało być wywołanie antyrosyjskiego powstania. Po wkroczeniu wraz z armią austriacką i niemiecką do Królestwa Kongresowego kompania kadrowa napotkała na wielkie trudności. Piłsudski nie spodziewał się takiej reakcji ludności polskiej, która odnosiła się podejrzliwie do polskich jednostek wojskowych. Przez to nie powiódł się plan wywołania ogólnonarodowego powstania. Głównym powodem nieufności Polaków wobec oddziałów strzeleckich było ich wkroczenie pod sztandarem dwóch zaborców. Atmosfera wkroczenia na ziemie Kongresówki jak i podporządkowanie polskich oddziałów zaborcom wywoływało wątpliwość, co do apelów niepodległościowych, jakie kompania kadrowa propagowała. Wkrótce władze wobec nieudanego planu Piłsudskiego zaczęły się domagać rozwiązania polskich formacji ${ }^{76}$. Jednak Piłsudskiemu z pomocą przyszli przedstawiciele Koła Polskiego. Dnia 16 VIII 1914 roku powołano Legiony Polskie, w których skład miały wchodzić wcześniej wspomniane oddziały jak i nowi ochotnicy. Zwierzchnictwo nad Legionami powierzono Naczelnemu Komitetowi Narodowemu (NKN). Natomiast pod względem strategicznym podlegały bezpośrednio dowództwu austrowęgierskiemu ${ }^{77}$.

Kraków, będąc strategiczną dla armii twierdzą, został powierzony administracji Komendy wojskowej. Wybuch wojny oraz przeniesienie prerogatyw do Komendy Twierdzy wprowadziło zamieszanie w Radzie Miejskiej. W 1914 roku w maju odbyło się jej ostatnie posiedzenie. Prezydentem miasta był wówczas Juliusz Leo ${ }^{78}$, natomiast wiceprezydentami: Henryk Szarski oraz Józef Sary. Rada Miasta zdawała sobie sprawę z sytuacji, w jakiej znalazł się Kraków. Konsekwencje, jakie wypływały z faktu, że Kraków był twierdzą, musiały w bliższej przyszłości dotknąć także mieszkańców miasta. Prezydent miasta, będąc jednym z założycieli wcześniej wspomnianego NKN, zwołał dnia 18 VIII nadzwyczajne posiedzenie Rady Miasta. Na wniosek prezydenta miasto Kraków przeznaczyło na fundusz wojenny (dla Legionów Polskich) milion koron. Drugą uchwałą było pobranie pożyczki dla podparcia miejskiego funduszu obrotowego. Dodatkowo uchwalono także nadzwyczajne podatki wojenne. W taki sposób miasto próbowało wprowadzić zabezpieczenie przed skutkami ekonomicznymi, jakie niosła ze sobą wojna ${ }^{79}$.

Skutki wojny i zbliżającego się frontu następowały bardzo szybko. W niedługim czasie zarówno ludność Krakowa, Galicji jak i pozostałych zaborów zaczęła

${ }^{76}$ J. Bator, Wojna..., s. 43. Po 13 VIII Władze austriackie widząc, że polskie działania w Kongresówce nie przynoszą jakichkolwiek działan zaczęły wcielać oddziały ochotnicze do pospolitego ruszenia.

${ }^{77}$ Tamże, s. 40-42; por. J. Buszko, Galicja 1859-1914. Polski Piemont?, Warszawa 1989, s. 76-79.

${ }^{78}$ J. Buszko, C. Bąk-Koczarska, Juliusz Leo, PSB XVII, s. 66-69.

${ }^{79}$ C. Bąk-Koczarska, Wladze miejskie Krakowa w latach wojny. [w:] Krakow w czasie I wojny swiatowej. Materiały sesji naukowej z okazji Dnia Krakowa w roku 1988, Kraków 1990, s. 72-73. 
odczuwać następstwa wojny, zwłaszcza pod względem ekonomicznym i gospodarczym. Zaczęły występować pierwsze ewakuacje jak i wysiedlenia ludności, nierzadko choroby i głód, które dziesiątkowały ludność. W tych ciężkich chwilach dla narodu polskiego pojawiła się iskierka pomocy płynąca $\mathrm{z}$ pałacu biskupiego $\mathrm{w}$ Krakowie.

W pierwszym tygodniu sierpnia arcybiskup lwowski Józef Bilczewski w porozumieniu z wszystkimi biskupami w Galicji, wydał 4 VIII 1914 roku odezwę: „Ukochani! Jeszcze nigdy $\mathrm{z}$ tak ciężkim jak dzisiaj sercem nie odzywałem się do Was. A jestem w tej chwili rzecznikiem zapatrywań i uczuć wszystkich czcigodnych biskupów polskich w kraju. Wojna! Wieść o niej dotarła do każdej wioski a zażądała ofiar niemal $z$ każdej rodziny. Wiele $z$ nich nie widzi już wśród siebie ojca, męża, syna. Opuścili co im najdroższe”. Dalej wspominał o obowiązku, jaki muszą spełniać żołnierze względem kraju, a także wyrażał wdzięczność wobec monarchii w osobie cesarza, pisząc: „Zaświadczą zarazem że umiemy być wdzięczni ukochanemu, sprawiedliwemu, Monarsze za to ze pozwolił być nam Polakami”. Odezwę kończył apelem o pomoc materialną w czasie wojny dla najbiedniejszych, szczególnie dzieci ${ }^{80}$. Tym orędziem Kościół katolicki pragnął zaakcentować polskiemu narodowi jego łączność i zadeklarować pomoc dla poszkodowanych w czasie wojny.

Na wiadomość o wybuchu wojny pomiędzy państwami centralnymi a Rosją biskup Sapieha powrócił 3 VIII do Krakowa z kuracji w Schönburn (w Szwajcarii) $^{81}$. Kolejnego dnia (4 VIII) Konsystorz krakowski wydał następujące zarządzenia dla duchowieństwa:

- aby kapłani we mszach świętych zamiast kolekty pro Papa dodawali kolektę ze mszy świętej Tempore belli,

- aby w każdym kościele codziennie przynajmniej jeden kapłan odmówił $\mathrm{z}$ ludem litanię loretańską,

- aby w niedziele $\mathrm{i}$ święta po sumie przed wystawionym sakramentem były odśpiewane suplikacje Przed oczy Twe Panie, Święty Boże i modlitwa w czasie wojny.

Szczególne rozporządzenia wydano proboszczom w parafiach, aby z ambon zachęcali ludność do przyspieszenia i ukończenia żniw oraz żeby wzywano do wzajemnej pomocy. Przekazano także pozwolenie księcia biskupa do wykonania koniecznych na roli robót $w$ niedzielę $i$ święta $w$ czasie wolnym od nabożeństw. Samych proboszczów powołano do otoczenia opieką sierot i wdów, a także opuszczonych i chorych. Wielu kapłanów zostało już wówczas powołanych do posługi duchownej w wojsku i w szpitalach, dlatego też wezwano nie powołanych do zgłoszenia miejsca swojego pobytu w celu przeznaczenia do pomocy duszpasterskiej ${ }^{82}$.

\footnotetext{
${ }^{80}$ Odezwa Episkopatu, „Głos Narodu” R: XXII (1914), nr 177, s. 1.

${ }^{81}$ AKMK, Liber..., z dnia 3 sierpnia 1914.

${ }^{82}$ Zarzadzenie Konsystorza krakowskiego, „Głos Narodu” R: XXII (1914), nr 180, s. 2.
} 
W Krakowie sytuacja z każdym dniem pogarszała się, zwłaszcza od chwili, kiedy nastąpiło faktyczne wypowiedzenie wojny. Sytuację tę w miesiącu sierpniu opisywał szczegółowo kapelan ks. bp. Sapiehy ks. dr Józef Niemczyński:

„Również Austria wypowiedziała wojnę Rosji. Prusy wkroczyły do Królestwa Polskiego. W Krakowie dużo wojska które powoli odchodzi. Najrozmaitsze wieść krążą jawnie lub potajemnie już to o zwycięstwach wojsk austriackich w Serbii już to o niepowodzeniach. W Krakowie i na prowincji brak drobnych pieniędzy. Ponieważ spodziewają się oblężenia Krakowa więc zapasy powoli robią. Bardzo dużo ludzi chodzi bez roboty. Wojskowość wyrzuca z klasztorów ludzi i dla wojska zabiera. Również dużo domów obraca na szpitale. Na Woli oddał Książę Biskup pałac Zakładowi Lubomirskich których wojskowość usunęła z ul. Rakowickiej. W opłakanym stanie znajduje się ten pałac. Meble zebrano na dół ze wszystkich pokoi $(\ldots)^{m 3}$.

W pierwszych miesiącach wojny miasto nie było oblężone przez wojska nieprzyjaciela. Jednak już wtedy skutki wojny były odczuwalne przez jego mieszkańców. Przede wszystkim dlatego, że Kraków był twierdzą pod zarządem Komendy Wojskowej, stąd pojawił się ogromny ruch rezerwistów i odjeżdżających z miasta oddziałów. Po drugie do opinii publicznej docierały różne sprzeczne informacje na temat działań wojennych ${ }^{84}$. Z każdym dniem zarówno dla mieszkańców Krakowa jak i okolicznych miejscowości niepewność jutra była coraz bardziej przerażająca.

\section{SYTUACJA NA FRONCIE (XVIII-XII 1914) \\ - EWAKUACJA KRAKOWA}

Tymczasem sytuacja na froncie gwałtownie się zmieniała. Na przełomie sierpnia i września ofensywa wojsk rosyjskich zaczęła nabierać tempa i monarchia naddunajska musiała wycofać się ze wschodniej Galicji. Konsekwencje tego manewru były bardzo poważne. Nowa linia frontu nad Sanem była wprawdzie sprawnie obsadzona, jednak zdawano sobie sprawę z możliwości jej utraty. Sytuacja była krytyczna dlatego też 13 IX armia austrowęgierska zdecydowała się na szybki odwrót na pozycje na linii Nida - Dunajec - Biała - Bieszczady. Manewr ten był wykonany bardzo szybko, co wiązało się wprawdzie $z$ dużymi stratami w żołnierzach, jeńcach i w sprzęcie, ale umożliwiło zajęcie wspomnianej pozycji już 20 IX. Ważnym uzgodnieniem austriacko-niemieckiej akcji było tzw. „chwilowe odstąpienie” od anektowania ziem Galicji wschodniej (w praktyce oznaczało to powrót do planu odbicia jej w bardziej dogodnym czasie $)^{85}$.

${ }^{83}$ AKKM, Liber.., z dnia 3 sierpnia 1914; por. B. Przybyszewski, Adam Stefan ..., s. 83. Austro-Węgry przystąpily do wojny z Rosją 6 sierpnia.; por. B. Przybyszewski, Kalendarium dzialalności spolecznej ks. bp. Adama Sapiehy podczas I wojny światowej, „Chrześcijanin w świecie” R: 14(1982), nr 8 (110), s. 107-132.

${ }_{84}$ J. Bieniarzówna, J. M. Małecki, Dzieje..., dz. cyt., s. 387. Na przelomie lipca i sierpnia do Krakowa przybyli chłopi z Ojcowa $\mathrm{z}$ informacją o opuszczeniu $\mathrm{z}$ terenów pogranicznych wojska i straży granicznej.

${ }_{85}$ J. Bator, Wojna., dz. cyt., s. 77-79. 
Pierwsze wiadomości o niepowodzeniach wojsk austriackich na froncie wschodnim (m.in. zdobycie przez Rosjan Lwowa) dotarły do Krakowa pod koniec sierpnia $^{86}$. Opinia publiczna $w$ Galicji była zszokowana. Wypadki na froncie, zwłaszcza utrata znaczącej części ziem prowincji, nadszarpnęły wiarę i zaufanie Polaków w możliwość zwycięstwa Monarchii Habsburskiej. Wzmagały się także antyniemieckie wystąpienia ludności przeciwko brutalności armii niemieckiej ${ }^{87}$. By zapobiec protestom, starano się zwłaszcza za pomocą prasy, wpływać na opinię mieszkańców (np. w kwestii bombardowania Kalisza) ${ }^{88}$. W tym czasie (27-28 VIII) biskup Sapieha odwiedzał rannych żołnierzy w szpitalach ${ }^{89}$. Przybywający z frontu ranni wraz z pojawiającymi się w Galicji przypadkami chorób zakaźnych wprowadzały do miasta coraz większy niepokój.

Punktem kulminacyjnym tego niepokoju była ogłoszona w połowie września (14 IX) ewakuacja mieszkańców Krakowa, która zdestabilizowała życie w mieście $^{90}$. Ewakuacja była spowodowana przewagą, jaką na froncie zdobywała Rosja. Wojska rosyjskie, stosunkowo szybko przemierzające ziemie Galicji Wschodniej, niebezpiecznie zbliżały się w kierunku Krakowa. Początkowo ewakuacja była dobrowolna, jednak takie rozwiązanie nie przynosiło wymaganych efektów ${ }^{91}$. Komenda twierdzy pelecała więc opuścić Kraków wszystkim osobom, które nie posiadały wystarczającej ilości żywności na czas oblężenia (3 miesiące). Zarządzenie w dużej mierze dotyczyło ludności najuboższej, która nie miała środków na zgromadzenie żywności na taki okres. Do obowiązków krakowskiego Magistratu doda-

${ }^{86}$ J. Bieniarzówna, J. M. Małecki, Dzieje..., dz. cyt., s. 387; por. J. Bator, Wojna..., dz. cyt., s. 63-70. Decyzja o stoczeniu drugiej bitwy lwowskiej (zwana potocznie bitwą pod Rawą Ruską) odbyła się w trudnej dla armii austriacko węgierskiej sytuacji. Zaskakujący był plan dowództwa - zaatakowanie przeciwnika na dużą skalę w stosunkowo krótkim czasie. Podstawowym celem było dwustronne oskrzydlenie Rosjan - na północ i południe od Lwowa. Ten manewr miał spowodować opuszczenie wcześniej zdobytego już przez Rosjan Lwowa. Problemem okazało się nie posiadanie wystarczającej przewagi ilościowej dlatego posuwano się $\mathrm{w}$ kierunku Lwowa bardzo wolno. Rosjanie walczyli z wielkim poświęceniem i nie zamierzali rezygnować z Lwowa - jego utrzymanie było jednym z pryncypialnych zamierzeń wojennych. Stąd po zaciekłej walce nie udało się zdobyć Lwowa. Co gorsza, linia frontu na tym odcinku musiała przesunąć się na niekorzyść wojsk austriacko-węgierskich. 12 IX wykonano odwrót. Pozbawiło to armię austrowęgierską szans na szybkie odzyskanie Lwowa.

${ }^{87}$ J. Bieniarzówna, J. M. Małecki, Dzieje.., dz. cyt., s. 378; por. J. Holzer, J. Molenda, Polska..., s. 72. Dodatkowo do mieszkańców Krakowa dobiegały wieści na temat postẹpowania Niemców na ziemiach Królestwa Polskiego jak i we Francji i Belgii. Niemcy szczególnie okazywaty wiele brutalności np. przy bombardowaniu Kalisza.

${ }^{88}$ Zajęcie Kalisza przez Prusaków, „Głos Narodu” R: XXII (1914), nr 180, s. 2. Podawano do wiadomości publicznej że bombardowanie było ostatecznością na jaką musiały się władze niemieckie zdecydować ze względu na częste strzelaniny urządzane w mieście przez ludność.

${ }^{89}$ B. Przybyszewski, Adam Stefan ..., dz. cyt., s. 83.

${ }^{90}$ J. Bienierzówna, J. M. Małecki, Dzieje..., dz. cyt., s. 387. Autorzy przywohują doniesienia prasowe $\mathrm{z}$ tamtego czasu: ,W mieście całym ruch, jakiego w Krakowie nigdy nie widziano(...) Oba dworce tj. osobowy i towarowy oblegane są przez wyjeżdżająca publiczność... w sklepach spożywczych ruch niezwykły. Publiczność od wczesnego ranka czyni zakupy mąki, krup, kaszy, cukru itd. Szereg sklepów zamknięto z powodu wysprzedaży towarów(...)".

${ }^{91}$ J. M. Małecki, Życie.., dz. cyt., s. 55. Autor podaje że pierwsze pociągi podstawione w Krakowie dla ewakuowanych nie wyruszyły gdyż zgłosiło się do nich tylko 9 osób. 
no sprawdzanie u mieszkańców wymaganego prowiantu. W prasie ukazywały się ogłoszenia przypominające o tym mieszkańcom:

„Magistrat krakowski w komunikacie nadesłanym do naszej redakcji przypomina mieszkańców Krakowa że w poniedziałek 21 komisje obchodowe powołane do życia przez c. i k. komendę twierdzy rozpoczną w prywatnych mieszkaniach sprawdzanie zapasów żywności o ile one wystarcza na okres 3 miesięcy. Ci wszyscy którzy dotychczas nie zaopatrzyli się w żywność na trzy miesiące powinni zrobić to natychmiast aby uniknąć przykrych następstw mianowicie przymusowego wydalenia z okręgu twierdzy(...)"992.

Kilka dni później (21 IX) do opinii publicznej podano kolejne przypomnienia w sprawie ewakuacji:

„Jeśli kto ma opuścić twierdzę według rozporządzenia wojskowości (czyli w Krakowie Ci którzy nie są dostatecznie zaprowiantowani) - to winien to uczynić po rygorem przymusowego wysiedlenia a uczynić ma to w terminie który będzie ogłoszony. Jeżeli kto sam posiada środki odpowiednie tzn. oświadczy komisji która będzie obchodziła mieszkania że posiada środki to może sobie wybrać miejsce dowolne gdzie chce jechać. Osoby które nie są w stanie utrzymać siebie i rodziny, mają to wobec komisji oświadczyć jakie roboty mogą ewentualnie wykonywać, a wiec pracę rolną, rzemieślniczą, kancelaryjną itp. (...) A każda gmina i każdy obywatel państwa musi przyjąć te osoby do robót do których się nadają .Osoby które nie nadają się do żadnej pracy będą internowane do miejsc które władza wyznaczy. Przymusowo wydaleni na koszt państwa mają prawo do bezpłatnego transportu do miejscowości dla nich przeznaczonej. Małoletnich, dzieci i rodziców, względnie opiekunów nie wolno rozdzielać. Koszty utrzymania przymusowo ponosi państwo. Utrzymania mają być obfite wg miary osób żyjących na miejscu które otrzymują płace tygodniową lub dzienną. Po 1 koronie za osobę dorosłą a po 60 ha za dzieci. Wypłata co 15 dni""93.

$\mathrm{Na}$ własną rękę opuszczały Kraków rodziny bogate, które wyjeżdżały do Wiednia lub innych miast położonych daleko od frontu. $\mathrm{Z}$ miasta wyjeżdżali też przedstawiciele banków, instytucji bankowych, którzy zawieszali swoją działalność. Kraków opuścił prezydent Juliusz Leo udając się do Wiednia (jednak po krótkim czasie wobec narastających problemów powrócił do Krakowa i dalej pełnił swoją funkcję) ${ }^{94}$. Wyjechało też prezydium miasta (Szarski złożył rezygnację

${ }^{2}$ Stwierdzanie zapasów żynności u mieszkańców m. Krakowa, „Głos Narodu” R: XXII (1914), nr 225, s. 1 .

${ }^{93}$ Przymusowe wydalanie z Twierdzy, „Glos Narodu” R: XXII (1914), nr 227, s. 2.

${ }^{94}$ C. Bąk-Koczarska, Wladze..., dz. cyt., s. 74-75. Przebywając już w Wiedniu prezydent Leo znalazł się w trudnej sytuacji. Rezygnując z prezydentury miasta utracił także pensję. Przyjaciele Lea zarówno z Koła Polskiego, jak na miejscu w Krakowie wysłali do Ministerstwa Spraw Wewnętrznych odwołanie od decyzji Namiestnictwa w sprawie powrotu prezydenta do Krakowa i restytuowania Rady Miejskiej. Jeszcze przed decyzją sam Leo zrezygnował z funkcji prezesa NKN, otrzymał obietnice powrotu do Krakowa jako prezydent i przywrócenia Rady. Nie czekając na wyniki odwołania przybył pod koniec listopada do Krakowa. Delegat Namiestnictwa Adam Fedorowicz przywrócił na urzędy prezydenta i wiceprezydentów miasta. Komisarz rządowy został odwołany. 
z urzędu a Sare wyjechał do Wiednia). W Krakowie pozostał Ernest Bandrowski (prof. chemii UJ oraz korespondent Akademii Umiejętności), który pełnił funkcję Delegata Rady. W takiej sytuacji prezydent Leo wystosował pismo do Namiestnictwa z prośbą o wyznaczenie zastępców (wielu przedstawicieli Rady Miejskiej opuściło Kraków). Dnia 9 XI Namiestnictwo powołało dla Krakowa komisarza rządowego, którym został Julian Nowak (profesor UJ). Do jego obowiązków należało sprawowanie pieczy nad sprawami miasta; przyznano mu także władzę polityczną pierwszej instancji. Oprócz komisarza powołano także dwóch zastępców: rektora UJ Kazimierza Kostaneckiego oraz wspomnianego wcześniej Ernesta Bandrowskiego. Otrzymali oni tzw. „radę przyboczną”, złożoną z 13 członków ${ }^{95}$.

W tej ciężkiej sytuacji dla narodu Książę Biskup krakowski nie szczędził sił, by jak najwydatniej nieść pomoc współrodakom. W dniach 20-26 IX książę Sapieha przebywał w Wiedniu. Pragnął wstawić się u rządu w sprawie przeprowadzonej ewakuacji, losu ewakuowanych jak i wszystkich z nią związanych spraw. Zakazał księżom opuszczania parafii w czasie działań wojennych oraz zarządził, by sprawowali opiekę nad ewakuowanymi. Proboszczowie i wikariusze otrzymali szerokie prerogatywy w sytuacjach, w których nie mogliby się skontaktować z Kurią Metropolitalną. Dnia 5 X 1914 roku Sapieha podzielił pałac biskupi i połowę oddał na rzecz seminarium duchownego ${ }^{96}$. Po powrocie (pod koniec września) z Wiednia zajął się sprawą zaopatrzenia Krakowa. W tym celu udał się do wiceprezydentów Szarskiego i Sarego, by upewnić się czy miasto zaopatrzy się w potrzebne surowce. Niepewność Sapiehy co do wystarczających zabiegów Urzędu Miasta w tym względzie wzbudzał brak podstawowych materiałów żywnościowych, jak: mleko czy jarzyny ${ }^{97}$.

Z początkiem listopada „walec parowy”, jak określano nacierającą armię rosyjską, napierał na umocnienia wojsk sprzymierzonych. Dlatego armia austrowęgierska musiała nakazać odwrót i obsadziła nowe pozycje na początku listopada ${ }^{98}$. Wkrótce okazało się, że umocnienia na linii frontu nie wytrzymają naporu Rosjan.

${ }^{95}$ C. Bąk-Koczarska, Wladze.., dz. cyt., s. 73-74.

${ }^{96}$ B. Przybyszewski, Adam Stefan..., s. 83-84. Wprowadził potrzebne regulacje dla duszpasterstwa wojskowego jak i opieki duchownej nad chorymi.

${ }^{97}$ Tamże, s. 84; por. W sprawie aprowizacji miasta, „Głos Narodu” R: XXII (1914), nr. 229, s. 1. Magistrat miasta wypowiedział się $w$ sprawie aprowizacji Krakowa: „1. Zakazuje wywozu $z$ obrębu Krakowa wszelkich artykułów niezbędnego użytku jak pieczywa, mięsa, wędlin, nabiału, jajek, mąki, kaszy, ryżu, grochu, jarzyn, owoców, cukru, kawy, herbaty, soli, octu, nafty, mydła, świec, węgla kamiennego, drzewa opałowego. 2.Nie wolno bez zezwolenia Magistratu zaniechać lub przerywać prowadzenia przemysłów handlowych, które mają jakąś łączność z aprowizacja miasta. pomocnicy handlowi i przemysłowi, którzy by przed prawidlowym rozwiązaniem stosunku shużbowego porzucili pracę, będą oprócz surowego ukarania przymusowo doprowadzani do objęcia pracy(...)".

${ }_{98}$ J. Bator, Wojna..., dz. cyt., s. 101. 1 Armia gen. Dankla znajdowala się pomiędzy Skałą a Częstochową. 4 Armia arcyksięcia Józefa Ferdynanda umacniała pozycję pomiędzy Skałą a Zakliczynem (Tarnów oddano 10 XI), 3 i 2 Armia obwarowały się w Karpatach do Przełęczy Lupkowskiej. Na tyłach Rosjan pozostawała twierdza Przemyśl (oblężona od 4 XI), która skutecznie przyblokowała drogę kolejową Tarnopol-Kraków. 
W takiej sytuacji wielce prawdopodobnym stało się podjęcie walk w okolicy Krakowa (jak i możliwej bitwy o samą twierdzę). Sam zresztą sztab państw sprzymierzonych przygotowywał plan operacji krakowsko-limanowskiej. Zamysłem głównodowodzącego armią austriacką Conrada von Hoetzendorfa było wprowadzenie modyfikacji planu sił niemieckich ${ }^{99}$. Wysuwając swoje wątpliwości co do pomyślnego wykonania owego manewru, Hoetzendorf, w miejsce planowanego przez siły niemieckie osłabienia centrum, postanowił przesunąc tam 2 Armię gen. Boehm-Ermoliego. Wykorzystując galicyjskie linie kolejowe w okolicach Krakowa, zamierzał przesunąć dywizje 4 Armii na lewy brzeg Wisły, w celu wykonania uderzenia na pozycje Rosjan. Przede wszystkim liczył on na powstrzymanie ,walca parowego", w najgorszym zaś razie przełamanie rosyjskiego otoczenia twierdzy. Cały plan musiał być wykonany błyskawicznie, ponieważ zamykając Rosjanom pochód na Berlin i Czechy odsłonięto drogę na Karpaty i na Węgry. W razie niepowodzenia planu wdarcie się sił rosyjskich na te tereny równoznaczne było $z$ klęską na terytorium cakej monarchii ${ }^{100}$.

To realne zagrożenie Krakowa zmusiło Komendę twierdzy do ogłoszenia ponownej ewakuacji mieszkańców, tym razem już przymusowej (6 X). Jak już wcześniej wspomnieliśmy wyjeżdżali przedstawiciele wszystkich klas społecznych. Najuboższych, którzy nie posiadali odpowiednich środków na podróż przewożono specjalnymi pociągami do baraków ewakuacyjnych na znajdujących się na terenie Austrii i Czech. Podróż tę często odbywali w ciężkich warunkach kondycyjnych jak i sanitarnych ${ }^{101}$. Na opuszczenie miasta zostawiono raptem kilkanaście dni (do 11 XI). Ks. Józef Niemczyński opisuje strach i popłoch w jaka wpadli mieszkańcy Krakowa: ,(..) wydano rozkaz natychmiastowej ewakuacji Krakowa. Thumy ludu ucieka albo przemocą wypędzają. Mówią o zbliżaniu się Moskali. Mają już być w Miechowie. Setki wozów ucieka (...)"102. Według statystyk od X 1914 do I 1915

${ }^{99}$ Tamże, s. 104-106. Dowództwo sił niemieckich m.in. w osobie Hindendurga opracowywało tzw. „kanneński plan”. Miał on na celu wycofać z centralnego odcinka frontu na północ większość 9 Armii Mackansena. Następnie w miejsce luki planowano zwabić oddziały rosyjskie pod twierdzę Kraków i tam dokonać manewru okrążającego.

${ }^{100}$ Tamże, s. 104-107.

${ }^{101}$ B. Przybyszewski, Adam Stefan..., dz. cyt., s. 84. Sapieha interweniował do Ministerstwa Spraw Wewnętrznych w Wiedniu $\mathrm{z}$ informacją o nieludzkim traktowaniu ewakuowanych w czasie podróży. Donosił Sapieże o tym jeden z księży który jechał z ludźmi - bez jedzenia, pieniędzy czy kwaterunku; por. Ewakuacja Krakowa, „Głos Narodu” R: XXII (1914), nr 233, s. 1. Ponieważ pierwsza ewakuacja nie była dobrowolna Magistrat poprzez prasę chciał zachęcić do opuszczania miasta, min. zapewniając biedniejszym jak najlepsze warunki, które w niedługim czasie okazały się mrzonką: „Wskutek obwieszczenia c. i k. Komendy twierdzy z dnia 14 br. Dotyczące opuszczenia krakowskiego okręgu fortecznego kursowały w czasie od 15 do 19 pociągi ewakuacyjne przeznaczone dla osób które nie mogą zapłacić za podróż koleją. W dalszym ciągu bẹdą kursować te pociągi do Wiednia. Osoby które są pozbawione jakichkolwiek środków do życia dla siebie i swych rodzin poza Krakowem otrzymają w części podróży na stacjach Przerów i Lundenburg bezpłatne pożywienie na koszt państwa i będą na koszt państwa w sposób odpowiadający wymaganiom sanitarnym i higienicznym w odpowiednich miejscowościach usadzone i przez cały czas pobytu aż do ustania obecnych wyjątkowych stosunków na koszt państwa żywione. Waga pakunków w pociągach tj.25 kg od osoby".

${ }^{102}$ AKKM, Liber..., $\mathrm{z}$ dnia 7 listopada 1914. 
roku Kraków opuściło 57 tys. mieszkańców, tj. 1/3 liczby ludności Krakowa ${ }^{103}$. Książę biskup Adam Sapieha oprócz organizowania pomocy dla miasta, jednocześnie zajmował się pomocą dla ewakuowanych. Ludzi, którzy przejeżdżali przez Kraków na Morawy starał się pocieszyć, podawał posiłki. Odwiedzał także szpitale, w których leżeli ranni żołnierze, m.in. w Kalwarii Zebrzydowskiej. Po ich zwiedzeniu interweniował w Festungskommando i przedstawiał przerażający stan w jakim znajdują się ranni. Po braku reakcji ze strony władz wojskowych Sapieha postanowił przeznaczyć część pałacu (wejście od strony Wiślnej) na szpital dla rannych żołnierzy ${ }^{104}$. Warunki w szpitalach pogarszały się - wielu żołnierzy, oprócz ran poniesionych w walce, cierpiało na tyfus plamisty, cholerę czy czerwonkę. Sapieha nieustannie odwiedzał rannych nie zważając na ich narodowość czy wyznanie ${ }^{105}$.

Położenie Krakowa stawało się z każdym dniem coraz trudniejsze. Od 12 XI pozamykano wszystkie sklepy i gospody. Wszyscy starali się ukrywać ważniejsze kosztowności i dzieła sztuki ${ }^{106}$. Budynki zabytkowe (w liczbie 36) w myśl konwencji haskiej zostały oznaczone białymi flagami z niebieskimi pasami. Ponieważ dowództwo cesarsko- królewskie złamało wcześniej kod rosyjski i przejęto depesze iskrowe, stąd dowódcy znali datę planowanego przez nieprzyjaciela ataku. Dnia 16 XI w Krakowie słychać było pierwsze odgłosy armatnie. W okresie bitwy podjęto w twierdzy obostrzenia: zamknięto bramy twierdzy, nikt nie mógł w tym okresie dostać się do miasta, nie wolno było też opuszczać fortecy m.in. w sprawie prywatnych aprowizacji ${ }^{107}$. Z Krzeszowic $(20 \mathrm{XI})$ przybyło wielu rannych, którymi zajął się biskup Sapieha. Interweniował także u kierownika służby medycznej w sprawie braku wystarczającej liczby lekarzy i pielęgniarek ${ }^{108}$. Dnia 22 XI po mieście poprzybijano ogłoszenia: ,że śmiercią karany będzie ten u którego znajdą się proklamacje wydane przez rząd rosyjski namawiające żołnierzy do zdrady" 109 . Wkrótce zabrakło wody, ludzie w mieście zaczęli wspominać o pokoju. Przez cały okres bitwy, do końca listopada, wzięto kilka tysięcy jeńców. Pośród jeńców była duża grupa Polaków, którzy witali Kraków okrzykami „Niech żyje Kraków!”"110. Front rosyjski pod koniec listopada zbliżył się od wschodu. Wkrótce armia rosyjska zajęła Wieliczkę (w nocy z 30 XI na 1 XII) i dotarła do linii Wieliczka - Dobczyce - Dobra. Rosjanie wkroczyli do Limanowej i Nowego Sącza. Niebawem (4 XII) rozpo-

${ }^{103}$ J. Bieniarzówna, J. M. Małecki, Dzieje..., dz. cyt., s. 388. Liczba ludności spadła z 183 tys. do 120 tys.

${ }_{104}^{104}$ B. Przybyszewski, Adam Stefan ..., dz. cyt., s. 85.

${ }^{105}$ Tamże, s. 85. Do Krakowa zwożono różnej narodowości (wyznania) rannych żołnierzy m.in. byli to Niemcy, Bośniacy. Sapieha odwiedził także szpital chorób zakażnych w Lobzowie gdzie wg podanych statystyk nie udało się wyleczyć tylko $6 \%$ żołnierzy.

${ }^{106} \mathrm{~J}$. Bieniarzówna, J. M. Małe cki, tamże, s. 388; por. AKKM, Liber..; ks. Niemczyński podaje że także bp Sapieha w nocy z $9 / 10$ XI rozkazał zamurować w piwnicy kosztowności.

${ }_{107}$ J. Bator, Wojna ..., dz. cyt., s. 109.

${ }^{108}$ B. Przybyszewski, tamże, s. 86. Ranni dodatkowo donieśli cierpień z powodu silnych odmrożeń.

${ }^{109}$ AKKM, Liber..., z dnia 25 listopada 1914.

${ }^{110}$ „Nowa Reforma” R: 33(1914), nr 506, s. 2; R: 33(1914) nr 514, s.2; por. J. Bator, tamże, s. 111. 
częła się bitwa o Kraków. Rosjanie, kiedy opanowali wsie Bieżanów i Bogucice, zaczęli odstrzeliwać fort Rajsko. Ponieważ już od 1 XII lotnictwo obserwowało pozycje Rosjan, sztab cesarsko-królewski mógł opracować plan przeciwdziałania. 6 XII rozpoczęto kontratak używając artylerii fortecznej wraz z załogą twierdzy ${ }^{111}$. Do walk wyjechały pociągi pancerne, a samoloty naprowadzały działa na stanowiska Rosjan ${ }^{112}$. Załoga po kilkugodzinnej krwawej walce wyparła Rosjan z Bieżanowa i zdobyła pasmo wzgórz pomiędzy Krakowem a Wieliczką. Podbudowana tymi sukcesami armia cesarsko-królewska poczyniła kolejne kroki w celu wyparcia Rosjan. Wielką rolę odegrała artyleria Krakowa. Dzięki jej sile już 5 XII Rosjanie musieli odsunąc się od twierdzy. 11 XII huk armat był coraz słabiej słyszany w Krakowie. Front przesunął się w kierunku Tarnowa. Dzięki ofiarnej postawie żołnierzy, udało się powstrzymać rosyjski „walec parowy”I13.

Wszystko w mieście podporządkowane było sytuacji, jaka wynikała z bezpośredniego zagrożenia Krakowa. Dnia 9 XII wojsko postanowiło przeznaczyć krakowskie kościoły na magazyny. Biskup Sapieha błyskawicznie interweniował u gen. Kuka skutecznie przeciwstawiając się takiej decyzji ${ }^{114}$. Po opuszczeniu przez Rosjan Wieliczki, Gdowa i Biskupic Sapieha udał się tam, by rozeznać się w zniszczeniach i potrzebach ludności. Po dokonanych obserwacjach 15 XII wydał odezwę, w której polecał zbieranie składek w kościołach. Składki te miały być przeznaczone na pomoc pokrzywdzonej ludności w wyniku prowadzonych działan wojennych ${ }^{115}$. Dzień później Komenda twierdzy wydała polecenie uzupełnienia trzy miesięcznych zapasów żywności. Jednocześnie zastrzegano, że zużycie tej żywności można było przeprowadzić tylko na rozkaz twierdzy. Za niestosowanie się do rozkazów groziły duże kary ${ }^{116}$.

\section{DZIALALNOŚĆ BISKUPA ADAMA SAPIEHY NA PRZELOMIE $1914 / 1915$ ROKU}

Biskup Sapieha nie ustawał $\mathrm{w}$ niesieniu pomocy poszkodowanym. 19 XII udał się do spustoszonego Bieżanowa. Napotkał tam wielką nędzę i trudne położenie ludności. By chociaż $w$ niewielkim stopniu poprawić ich sytuację, zakupił $z$ własnych funduszy w Magistracie Krakowskim: zapałki, naftę oraz sól ${ }^{117}$. Wszę-

\footnotetext{
${ }^{111}$ AKKM, Liber.., z dnia 6 grudnia 1914. Kapelan bp. Sapiehy podaje że z 5/6 grudnia tak silne byly strzaly armatnie że aż Palac caly sie trzast $i$ Ksiązę biskup cala noc nie spal (...) Huk musiał być ogromny, wszakże front znajdował się $10 \mathrm{~km}$ od Rynku Głównego.

112 J. Bator, Woina..., dz. cyt., s. 119.

${ }^{113}$ Tamże, s. 98-139.

${ }^{114}$ B. Przybyszewski, Adam Stefan..., dz. cyt., s. 86. Głównym celem wojska było zaopatrzenie i wzmocnienie twierdzy. Zajmowanie kościołów pod magazyny rozpoczęto od kościoła św. Katarzyny. Składowano tam siano i słomę; por. R. M. Zawadzki, Biskup Adam Sapieha podczas pierwszej wojny światowej, [w:] Kardynat Adam Stefan Sapieha-środowisko rodzinne, życie i dzieło, Przemyśl 1995, s. 147.

${ }^{115}$ B. Przybyszewski, Adam Stefan..., dz. cyt., s. 86.

${ }^{116}$ AKKM, Liber..., z dnia 16 grudnia 1914 roku.

$1^{-}$B. Przybyszewski, Adam Stefan..., dz. cyt., s. 87.
} 
dzie, tam gdzie można było się dostać, by wesprzeć pokrzywdzoną ludność, Sapieha zawsze spieszył z pomocą ${ }^{18}$. Wstępne informacje na temat poszkodowanej ludności przesyłali poprzez korespondencję listowną księża, którzy przebywali na terenach, gdzie toczyły się bitwy. Listy te były bardzo pomocne w pozyskiwaniu informacji na temat zniszczeń jak i potrzeb ludności. Znajdziemy wiele przykładów informowania Sapiehy w taki sposób. Przedstawiony poniżej zawiera relację księdza Józefa Wróbla (przełom XI i XII 1914) z terenów, na których były prowadzone działania wojenne.

(...) Stosując się do życzenia najprzewielebniejszego Księcia Biskupa przesyłam wiadomości dotyczące parafii za Rabą. 27 listopada pojawiły się tam pierwsze straże kozackie; Wkrótce przybyły wojska liniowe i bawiły $10 \mathrm{dni}$. Z 5 na 6 grudnia wsie tamtejsze, szczególnie Lubomierz, Karpanów, Tarnawa były terenem bitwy. Straty w ludziach cywilnych są nieznane. W Rempanowie zginęlo troje i jeden wypadek zamordowania przez kozaków. Bardzo wiele ucierpiała ludność pod względem materialnym. O ile zaś nie ukryte zbyt zrabowano wszystko. Zboże w snopach stratowane końmi, wymłócone i paszę zabrali. Szczególnie zabierali konie np. ojcu zabrali konie wszystką paszę i zboże. W czasie bitwy padało wiele zwierząt domowych od kul karabinowych. Ludzie kryli się $w$ piwnicach lub lochach podziemnych. W mieszkaniach nie można było usiedzieć, przez ściany przechodziły kule. $\mathrm{W}$ domu rodzinnym przeszło ich 10 . Ucierpiała też ludność moralnie wiele. Słyszałem o kilku wypadkach zgwałcenia, nawet w rodzinnej mojej wsi chciano uprowadzić dziewczynę. Księża proboszczowie wszyscy zostali na swych stanowiskach, co bardzo dodatnio wpłynęło na ludność. Plebanie nie były tak ograbione, gdyż tam zjeżdżała starszyzna, a ich obecność do pewnego stopnia tamowała grabież. Zabrano też wielu ludzi jako podejrzanych o szpiegostwo. Wielu $\mathrm{z}$ nich po tygodniu wróciło, jednak niektórzy jeszcze nie wrócili i nie wiadomo co się $z$ nimi stało. Rozmawiałem $z$ jednym takim co powrócił, opowiadał że związanych ze sobą czterech za ręce gnano najeżdżając końmi i nieraz wpadali do przykop. Jeden $z$ Łapanowa podczas takiej podróży zmarł. Okoliczne wsie takie jak Góra św. Jana - prawie doszczętnie zniszczone. Pamięć pobytu Kozaków głęboko wyszła się w pamięć ludności z powodu nie ludzkiego obchodzenia się. Toteż kiedy w poniedziałek pojawiły się nasze wojska wstali i ich ze łzami radości, jako wybawców od „czarnych" tak nazywają kozaków ${ }^{119}$.

${ }^{118}$ Tamże, s. 87. Gdy tylko wojska państw sprzymierzonych odparły ofensywę rosyjską dnia 26 XII Sapieha wyruszył w do Dziekanowic, poprzez Dobczyce aż do Myślenic. We wszystkich tych miejscowościach dowiadywał się na temat położenia mieszkańców, wyshuchiwał skarg m.in. w Myślenicach krytykowano zniszczenia jakich dokonało węgierskie wojsko. Wszędzie pozostawiał pewną sumę pieniędzy na najpilniejsze potrzeby.

${ }^{119}$ AKKM, Teki Sapieżynskie (dalej TS) VI/11, Relacja ks. Wróbla z terenów objętuch dzialaniami wojennymi z dnia 17 lutego 1914 roku. 
W wigilię Bożego Narodzenia Książę Biskup odwiedził szpital wojskowy w pałacu biskupim gdzie przebywali ranni żołnierze. W bramie pałacu przyjął go dr Wilczyński wraz z oficerami z innych szpitali. Na cześć biskupa wygłosili mowę dziękczynną: dr Ryszard Lang oraz wyżej wspomniany dr Wilczyński. W dowód wdzięczności za opiekę jaką otoczył biskup rannych żołnierzy wręczono mu żelazną kasetę z ziemią spod „drzewa wolności” wraz z cegiełką z kościoła Najświętszej Marii Panny. Książę Sapieha podzielił się opłatkiem z żołnierzami i wręczył im pamiątkowe książeczki do nabożeństwa $z$ własnoręcznym podpisem ${ }^{120}$.

Wszystkie działania Sapiehy począwszy od wybuchu wojny skierowane były na akcje pomocy najbiedniejszym i poszkodowanym w wypadku działań wojennych. Ówczesne działania biskupa wobec rozmiaru tragedii narodu polskiego nie były wystarczające. Książę biskup zdawał sobie sprawę z ogromu wojny i z potrzeb jakie wynikły w trakcie jej trwania. Przedstawiał to wszystko we wspomnianym już wcześniej Dziesięć lat po ingresie pisząc:

(...)Wybuchła wojna była pod wieloma względami i dla moich stosunków osobistych choć bardzo ciężka jednak odświeżająca. Kraków opustoszał groza chwili pospędzała w cień wiele dawniejszych małych wielkości. W samym początku tak byli wszyscy zajęci ratowaniem siebie i dobytku że na co innego nie było miejsca. Ja też musiałem bronić przed głupotą i złością wojska kościołów, zakonów, kapłanów i świeckich że właściwie tylko o tem można było myśleć. Uratowaliśmy seminarium umieszczając je w pałacu biskupim chodziło o to by rzeczy szły jak mogą. Zniszczenie kraju, które nam wtedy wydawało się niesłychane a które póżniej przez dalsze skutki wojny okazało się tylko początkiem klęski wywołało potrzebę ratunku(... $)^{121}$.

W miarę pogłębiania się dramatycznej sytuacji ludności Sapieha postanowił przedsięwziąć kroki w celu stworzenia akcji humanitarnej, która swoim zasięgiem dotarłaby do większości ludzi poszkodowanych, bezdomnych, sierot, chorych i rannych. Jednakże warunki do tego, by przeprowadzić taką akcję były bardzo trudne. Najważniejszą przeszkodą była trudna sytuacja materialna nie tylko najuboższych, lecz także bogatszych elit. Prawie każdy poniósł straty na wojnie, stąd ofiarność ze strony społeczeństwa była znikoma. Niemniej jednak, pomimo wojennych perturbacji i ciężkiej koniunktury, zapotrzebowanie na pomoc było wielkie i wymagało natychmiastowej interwencji ${ }^{122}$. Zapowiedzią takiego działania była ułożona przez Sapiehę odezwa do całego chrześcijańskiego świata ogłoszona 25 XII 1914 roku:

${ }^{120}$ B. Przybyszews ki, Adam Stefan ..., dz. cyt., s. 87.

${ }^{121}$ AKKK, Dziesięc lat po ingresie, b. sygn.

${ }^{122}$ Trzy lata dzialalności KBK. Sprawozdanie Książęco-Biskupiego Komitetu Pomocy dla Dotkniętych Kleskạ Wojny za lata 1915-1917, Kraków 1918, s. 4-5. 
Wśród tych zwykle tak radosnych Świąt Bożego Narodzenia, które właśnie obchodziliśmy jakże serca nasze $w$ tym roku były przepełnione bezmierna boleścią! Kiedy dusza nasza rwała się ku Bogu, by $\mathrm{z}$ aniołami śpiewać $\mathrm{Mu}$ chwałę na wysokości, a wypraszać na ziemi pokój ludziom dobrej woli, zewsząd dolatywał nas jęk kroci rannych, kalek, chorych, widmo najbliższych poległych stawało przed naszymi oczami. Nie pokój na ziemi, ale wojna, straszna wojna, najokrutniejsza jaka kiedykolwiek ludzkość przechodziła ta wojna rozszalała się tuż za bramami naszego miasta, wśród naszych wsi i miast.

Dwa działy naszego kraju: Królestwo Polskie i Galicja są od miesięcy polem tej najstraszniejszej wojny. Groza zawisła nad pokoleniem dzisiejszym i przyszłym. Pomijam tragedie dusz która na tem polega, że Polacy stawać muszą do szeregu przeciwko własnym braciom, godzić na ich mienie i życie. Dziś wyłącznie wzgląd ludzki mamy na oku i z głębi skrwawionego serca przemówić zamierzamy do uczuć ludzkich do serc szlachetnych wszystkich narodów.

Wojna dzisiejsza ze wszystkimi narzędziami zniszczenia zaciążyła strasznie nad biedną ziemią naszą, Jej bezlitosność odbiła się krwawą wymową na naszych siołach i łanach. Miasta zapadły się w zgliszcza i rumowiska, zniknęły zagrody i chaty, ciągle przemarsze milionowych armii i bezustanne walki zmiażdżyły dobytki znoju i potu pokoleń, kultury i dorobku wieków. Wśród pustyni biegną między złomami tysiące ludzi bez dachu i schronienia nad głową, widmo głodu, chorób już nie tylko zagraża przyszłości lecz przygniata swem brzemieniem całe rodziny pozbawione dachu, mienia, i najniezbędniejszych środków do życia! Zniszczenie prawie zupełnie objęło terytorium cztery razy większe od bogatej, lecz równie nieszczęśliwej Belgii. Żadne słowo nie potrafi opisać ogromu tej klęski, trzeba by ją objąć i patrzeć na nią własnymi oczyma.

Jeżeli los zarządził że padliśmy ofiarą tej okrutnej walki, to ludzkość wymaga, by choć w części jej skutki zostały złagodzone, by nie dopuścić do powstania głuchej pustyni wśród świata, by nie pozwolić mrzeć z głodu i zimna tysiącom, milionom bezbronnych. Do uczuć też ludzkich i chrześcijańskich całego świata nie wahamy się dziś zaapelować w poczuciu łączności ludzi, która mimo grozy wojny żyje i jak tuszymy, jej okropności przeżyje. Wzywamy więc wszystkich bo sami nie zdołamy uśmierzyć ran tej niebywałej klęski, rodaków i innych narodów ludzi mających serce by spieszyli z czem kto może.

Nasz stary Kraków dwa razy już w tej wojnie był w bliskim niebezpieczeństwie ale P. Bóg go uchronił, czy nie na to, by jak w ciągu wieków, tak i teraz był sercem krwią spływającej, pożogą Polski. Musi ona ją cała przygarniać, otoczyć opieką, za wszystkich, którym to dziś nie możliwe, przemówić. 
Niech więc $z$ Krakowa wyjdzie wołanie i prośba do wszystkich bliskich i dalekich, by wyciągnęli miłosierną rękę ${ }^{123}$.

Ta wzruszająca odezwa miała szczególny wydźwięk w dniu Świąt Bożego Narodzenia. Zaraz po Nowym Roku została zamieszczona w „Notificationes”. Pojawiła się także w prasie lokalnej („Czas”, „Głos Narodu”) jak i w kilku innych dziennikach zagranicznych: „L'Osservatore Romano”, „Kölnische Volkszeitung”, „Reichpost”, „Slovenec” oraz w pismach amerykańskich ${ }^{124}$. Biskup krakowski w swoim przesłaniu apelował o pomoc dla dotkniętego tragedią narodu. Polacy $z$ wiarą i nadzieją reagowali na to orędzie. Książę Biskup liczył na to, że odezwa skierowana bezpośrednio do narodów chrześcijańskich przyniesie dzieła miłosierdzia w postaci darów (pieniężnych jak i w naturze) dla poszkodowanych Polaków. Atmosferę, jaka nastąpiła zarówno na ziemiach polskich jak i w świecie opisywał ks. dr J. Niemczyński „,...) Książe biskup dał 3 I 1915 do druku odezwę daną do całego świata $z$ prośbą dla tych których dotknęła klęska wojny. Ta odezwa wywołała ogromne wrażenie gdyż ani Rząd ani koło polskie ani dawni obrońcy ludu ala Daszyński (...) Stapiński tem sie nie zajęli (...) Ks. Ślepicki został skarbnikiem"125. Kapelan biskupa przesadnie podkreślał rozbieżności co do kwestii organizacji pomocy poszkodowanym. Aczkolwiek nie można przekreślać faktu, że opinia publiczna uważała, iż Koło Polskie nie wystarczająco udzielało się na rzecz sprawy polskiej. Trzeba przyznać także, że dzieło miłosierdzia biskupa krakowskiego wobec pokrzywdzonych okazało się jedną z nielicznych akcji humanitarnych przeprowadzanych na terenie naszego kraju.

Do Krakowa spływało wiele listów z poparciem dla biskupiej inicjatywy. Egzemplifikacją tego poparcia był list jednego $z$ profesorów Uniwersytetu Jagiellońskiego, późniejszego członka Komitetu, Stefana Jentysa do biskupa krakowskiego Sapiehy (4 I 1915). Przytaczał on w nim sprawozdanie z obrad posłów włościańskich do sejmu mówiące o tragedii, jaka nawiedziła naród polski: „Wsie polskie przedstawiają dzisiaj obraz największej nędzy i rozpaczy. Ziemia stratowana i zniszczona, roboty w polu stają odłogiem bo nie ma sił roboczych ludzkich ani zwierzęcych, ludność znajduje się bez chleba i bez grosza, drogi zrujnowane, hodowla bydła zniszczona na całe lata, choroby epidemiczne szerzą się, nad całym krajem zawisło widmo potwornego głodu(...)"126. W dalszej część listu wyrażał szeroko idące poparcie dla odezwy o pomoc do chrześcijańskiego świata, przy okazji samemu włączając się poprzez ofiarowanie datku pieniężnego. Poniżej prezentujemy fragment tego listu.

${ }^{123}$ AKKM, T.S. VI/14, List bp. Sapiehy do wiernych z dnia 31 grudnia 1914 roku, T. S. VI/15, Projekt Odezwy z 25 grudnia 1915 roku; por. „Trzy lata dzialalności KBK, Kraków 1918, s. 5-7; por. R. M. Zawadzki, tamże, s. 147; por. A. Baciński, Dzialalność..., s. 265-275; por. „Czas” R: 68(1915) nr 7, s.1; por. Odezwa, „Glos Narodu”, R:XXIII (1915), nr 5, s.1.

${ }^{124}$ Trzy lata dzialalności KBK, s. 7; por, R. M. Zawadzki, Biskup..., dz. cyt., s. 147.

${ }^{125}$ AKKM, Liber..., z dnia 4 stycznia 1915.

${ }^{126}$ AKKM, T.S. VI/19, List prof. S. Jentysa do bp. Adama Sapiehy z 4 stycznia 1915 roku. 
(...) Naród nasz który dla szalejącej wojny światowej tyle bez szemrania oddał, najwięcej został dotknięty. Kraj taki podatek krwi i mienia z obowiązku i dodatkowy ponad możność (...) z dobrej woli dla dobra całego państwa złożył że ratunek od wszystkich krajów mu się należy (...) odezwa do wszystkich narodów się zwracająca niezawodnie nie zawiedzie. Ale są łzy do starcia, ale są nieszczęśliwie głodni, których zaraz trzeba nakarmić, są chorzy którym ulga $\mathrm{w}$ cierpieniach się należy; wiec i doraźna pomoc jest niezbędną. W myśl chrześcijańskiej zasady: ,pomagaj sam sobie a Bóg Ci dopomoże". Nie wątpię ze szlachetne słowa odezwy Najprzewielebniejszego Księcia Biskupa i wśród polskiego społeczeństwa żywem odezwą się echem, przeto jako skromny ofiarę jestem złożyć 200 koron tyle na ile stać trochę więcej posiadającego i sytego - dla najbiedniejszych i najwięcej potrzebujących pomocy ${ }^{127}$.

Odezwa de facto rozpoczynała choć jeszcze nie formalnie działalność nowo powstałego Komitetu. Pomimo tego, że ukonstytuował się on dopiero w maju 1915 pod nazwą Krakowski Biskupi Komitet Pomocy dla Dotkniętych Klęską Wojny (powszechnie nazywanym Książęco Biskupim Komitetem lub KBK ${ }^{128}$ ) organizację pracy rozpoczęto jüż od pierwszych dniach stycznia ${ }^{129}$. W dalszej części pracy powrócimy do przedstawienia szczegółowo kwestii organizacyjnych Komitetu.

\section{INICJATYWY NA RZECZ POSZKODOWANYCH PRZEZ WOJNE}

Niewątpliwie skutki wojny mobilizowały ludzi różnych stanów, wyznań do tworzenia komitetów czy też organizacji przyczyniających się do poprawy losu współrodaków. Powołanie Książęco Biskupiego Komitetu nie było precedensem, jeśli chodzi o tego typu instytucje na ziemiach polskich. Jednak można pokusić się o stwierdzenie, że był on w tamtym okresie jednym $\mathrm{z}$ najważniejszych komitetów na tym obszarze.

W pozostałych zaborach nowo powstałe komitety, podobnie jak Krakowski Komitet, nastawione były na prowadzenie działalności humanitarnej i charytatywnej (w okresie wojny nawiązywał on często z nimi współpracę). W Królestwie Polskim taką rolę spełniał Centralny Komitet Obywatelski (CKO) zatwierdzony przez władze rosyjskie 10 IX 1914 roku. Skupiał wśród swoich członków różne osobistości instytucji gospodarczych w dużej mierze wywodzące się z Centralnego Towarzystwa Rolniczego. Przewodniczącym CKO został Anton von Essen (generał -

\footnotetext{
127 Tamże.
}

${ }^{128}$ TS VI/31, List W. Czartonskiego do bp. Adama Sapiehy z 11 marca 1915 roku. W liście do Sapiehy W. Czartoryski pisze o propozycji ustalenia skrótu (...) Jè̇eli można to lepiej zmienić BKK na KBK bo to niepotrzebnie robic ludzie bẹda żarty z dwóch ostatnich liter.

${ }^{129}$ Trzy lata dziatalnosici $K B K$, s. 11. 
gubernator warszawski). Natomiast w skład zarządu CKO wchodzili Seweryn Czetwertyński (prezes), Władysław Grabski (zastępca) oraz Stanisław Karpiński (skarbnik). Głównym celem CKO było zachowanie ładu społecznego i ekonomicznego w Królestwie. Komitet ten zobowiązał się też do pomocy ludności pokrzywdzonej w wyniku działań wojennych, organizacji żywności i pomocy materialnej. CKO będąc komitetem nadrzędnym sprawował pieczę nad pozostałymi instytucjami o podobnym zakresie działającymi w zaborze rosyjskim. Po wkroczeniu do Warszawy wojsk niemieckich nowe władze postanowiły rozwiązać Centralny Komitet, co wiązało się jednoznacznie $\mathrm{z}$ rozwiązaniem komitetów miejskich i gminnych. Wszystkie dochody tej organizacji po rozwiązaniu zostały przekazane różnym instytucjom charytatywnym (1 290 rubli $)^{130}$.

Po zajęciu Warszawy przez wojska niemiecko-austriackie oraz zlikwidowaniu CKO władze zgodziły się na powołanie organizacji o podobnej działalności. Potrzeba była nagląca, ponieważ jej istnienie zależało od przywozu żywności z Ameryki do Królestwa. W gruncie rzeczy zmieniono nazwę CKO na Krajową Radę Opiekuńczą (Rada Główna Opiekuńcza-RGO). W jej skład wchodzili poprzedni członkowie zarządu CKO. Prezesami byli Stanisław Dzierzbicki oraz Adam Ronikier. Powołanie rastąpiło 12 XII 1915 roku, natomiast oficjalne zatwierdzenie 1 I 1916 roku. Celem RGO było „niesienie pomocy poszkodowanej przez wojnę ludności, bez różnicy wyznania”. Na fundusze RGO składały się przekazy pieniężne od Komitetu Poznańskiego, Komitetu Krakowskiego oraz władz okupacyjnych $^{131}$.

W Poznaniu 5 II 1915 roku ukonstytuował się (z inicjatywy Rady Narodowej) Komitet Niesienia Pomocy w Królestwie Polskim. Do 20 II funkcję przewodniczącego piastował abp Edward Likowski. Po jego śmierci prezesem tej instytucji został abp Edmund Dalbor, a wiceprezesem został Ludwik Mycielski. Komitet ten wydał odezwę 9 II 1915 roku, apelującą o składanie pieniędzy na rzecz pomocy ludności w Królestwie Polskim. Poznański Komitet po zajęciu przez państwa centralne Królestwa Polskiego rozszerzył swoją działalność. Udało mu się także nawiązać współpracę z Radą Główną Opiekuńczą oraz wysłać swoje komisje w celu zebrania informacji na temat potrzeb w Królestwie ${ }^{132}$.

${ }^{130}$ D. Płygawko, Polonia devastata - Polonia i Amerykanie z pomoca dla Polski, Poznań 2003, s. 50-53; por. D. Płygawko, Sienkiewicz w Szwajcarii, $Z$ dziejów akcji ratunkowej dla Polski w czasie $I$ wojny światowej, Poznań 1986. (Kontynuacją działalności CKO było powstanie Centralnego Komitetu w Piotrogrodzie - 24 VIII 1915 r. Organizacja ta niosła pomoc polskim uchodźcom. Jej działalność zakończono 22 lipca 1918 roku.

${ }^{131}$ D. Płygawko, Polonia ..., dz. cyt., s. 62-64.

${ }^{132}$ Tamże, s. 59-61. 


\section{WSPÓEPRACA Z KOMITETEM VEVEYSKIM}

Szczególną rolę w czasie I wojny światowej odegrała polska emigracja w Szwajcarii ${ }^{133}$. Pragnęła ona skutecznie propagować sprawę polską na arenie międzynarodowej. Wśród emigrantów przede wszystkim wyróżniały się osoby, które wyjechały z kraju ze względów politycznych. Dużą grupę stanowili też przedsiębiorcy i robotnicy oraz studenci polscy, którzy przebywali w ośrodkach uniwersyteckich w Genewie i Zurichu ${ }^{134}$. Po wybuchu wojny zawiązały się w Szwajcarii (zwłaszcza we francuskich kantonach) organizacje polityczno-informacyjne. Należy tutaj wymienić: Stowarzyszenia La Pologne et la Guerre (w 1917 roku zmieniło nazwę na Union Nationale Polonaise), Agence Polonaise Centrale (tzw. Agencja Lozańska) oraz Centralne Biuro Prasowe NKN w Rapperswillu ${ }^{135}$.

Z początkiem wojny do Szwajcarii przedostało się wiele polskich osobistości, m.in.: Antoni Osuchowski ${ }^{136}$, Erazm Piltz ${ }^{137}$ czy Henryk Sienkiewicz ${ }^{138}$. Ten ostatni na początku wojny przedostał się wraz z rodziną z Kielc do Krakowa. W chwili kiedy Krakowowi zagrażała ofensywa rosyjska, wyjechał do Austrii. Sytuacja w Wiedniu, zwłaszcza niesłuszne przypisanie jego autorstwa deklaracji politycznej przeciwko państwom centralnym, zmusiła go do ponownego wyjazdu ${ }^{139}$.

Sienkiewiczowi udało się przedostać do Szwajcarii, gdzie zamieszkał wraz $z$ rodziną w Vevey. Była to niewielka miejscowość letniskowa położona nad Jeziorem Genewskim. Od początku wojny w Szwajcarii przebywał Ignacy Jan Paderew$\mathrm{ski}^{140}, \mathrm{z}$ którym po przybyciu na miejsce Sienkiewicz nawiązał kontakt. Pomysł powołania komitetu, który koordynowałby akcję ratunkową dla ziem polskich przedstawił Erazm Piltz. Zarówno Sienkiewicz, Paderewski jak i Osuchowski przystali na ten plan, gdyż uznali, że regularny dopływ pomocy finansowej oraz materialnej dla Polski zapewnić mogła jedynie instytucja działająca poza granicami jej $\mathrm{kraju}^{141}$. Pozwolenie na utworzenie Komitetu wydal prezydent Konfederacji Szwajcarskiej - Giuseppe Motty ${ }^{142}$. I tak 9 I 1915 roku w Lozannie ukonstytuował się Generalny Komitet Pomocy Ofiarom Wojny w Polsce (Comitè Gènèral pour les

${ }^{133}$ Szwajcaria od Kongresu Wiedeńskiego posiadała status neutralności- przyp. aut.

${ }^{134}$ D. Płygawko, Polonia..., dz. cyt., s. 96; por. D. Płygawko, Sienkiewicz w Szwajcarii..., dz. cyt., s. 5-7. W Vevey mieszkali przez rok w Grand Hotelu, natomiast po zamknięciu go w Hotelu du Lac.

${ }^{135}$ D. Płygawko, Polonia.., dz. cyt., s. 96-102. Autorka przybliża wyczerpująco powstanie tych organizacji jak i przedstawia najważniejsze założenia programowe.

${ }^{136}$ Zob. J. Hulewicz, Antoni Osuchowski, PSB XXIV, s. 594-601.

${ }^{137}$ Zob. A. Szklarska Lohmannowa, Erazm Piltz, PSB XXVI, s. 293-298.

${ }^{138}$ Zob. H. Markiewicz, Henryk Sienkiewicz, PSB XXXVII, s. 203-215.

${ }^{139}$ D. Płygawko, tamże, s. 97. W Wiedniu Sienkiewicz spotkał Antoniego Osuchowskiego, którego przekonał do wyjazdu do Szwajcarii. Dołączył do nich także Szymon Askenazy z małżonką oraz Erazm Piltz.

${ }^{140}$ zob. M. Perkowska, R. Wapińsk i, Ignacy Jan Paderewski, PSB XXIV, s. 795-802.

${ }^{141}$ D. Płygawko, tamże, s. 103. Autorka przywohuje wspomnienia Paderewskiego na temat prowadzonych rozmów o kształcie i celach Komitetu w domu Paderewskiego.

${ }^{142}$ AKKM, T.S VI/23, List H. Sienkiewicza do bp. Adama Sapiehy z 2711915 roku. W liście do Sapiehy Sienkiewicz wspomina że ... p. Motta przyjąl mvśl utworzenia Komitetu z największa życzliwościa i przyrzekl go otoczyć opiekg wlasną i opiekg rady zwiazkowej(...). 
Victimes de la Guerre en Pologne) $)^{143}$. Ponieważ główna siedziba Komitetu mieściła się w Vevey funkcjonowal on także pod nazwą Komitet Veveyski. Na pierwsze, założycielskie spotkanie zaproszono elitę polskiej emigracji. Honorowymi prezesami Komitetu byli: Henryk Sienkiewicz i Ignacy Jan Paderewski. Posiadali oni w momencie powstania Komitetu status międzynarodowych sław, co miało być dodatkowym atutem w pozyskiwaniu funduszy dla Polski. Komitetem zarządzała Rada Wykonawcza, którą kierował Antoni Osuchowski ${ }^{144}$. Choć autorem statutu był Erazm Piltz, to inni członkowie posiadali także wpływ na to jak przebiegać miał jego ostateczny kształt. Głównym celem zapisanym w statucie była organizacja pomocy międzynarodowej dla ofiar wojny w Polsce. Komitet miał za zadanie zbierać dary pieniężne oraz tworzyć komitety lokalne we wszystkich krajach, w których apelowano o pomoc dla Polski ${ }^{145}$.

Generalny Komitet Pomocy Ofiarom Wojny już w styczniu nawiązał kontakt z biskupem krakowskim Sapiehą. W liście do Sapiehy (z dnia 27 I 1915 r.) Henryk Sienkiewicz informował go o powstaniu Komitetu Veveyskiego: „(...) Jak dalece konieczność pomocy dla Królestwa i Galicji narzuciła się siłą rzeczy wszystkim Polakom, dowodem na to jest, że w chwili w której otrzymaliśmy wspaniałą odezwę W. Ekscelencji tworzył się w Lozannie się Komitet z celem odwołania się o taką pomoc do wszystkich narodów chrześcijańskich świata (..." ${ }^{\$ 146}$. Wspomniał także o postanowieniach Komitetu i wystosowaniu w jego imieniu prośbę: „(...)Ośmieliliśmy się w liście członków z Galicji umieścić i nazwisko ks. Ekscelencji i umieściliśmy je na pierwszym miejscu, jako duchowego pasterza naszego narodu, obecnie zaś dołączamy gorącą prośbę o zgodę na to i przynależność do Komitetu, ze względu na jego cel i działania (...."147. W dalszej części listu przedstawił cel, jaki przyświecał Komitetowi, a także, jakie działania mają pomóc go osiągnąć: „,...) Cel Komitetu (...) jest czysto filantropijny, obcy wszelkim orientacjom i wszelkiej polityce, tak że jedynym naszym zadaniem będzie dostarczyć chleba głodnym, zboża na zasiew rolnikom oraz podnieść z ruin zburzone wioski i miasteczka. Liczymy na pomoc wszystkich po trochu narodów, lecz głównie na Stany Zjednoczonej Północnej Ameryki, w których książki moje znane są powszechnie, a osoba i artyzm Paderewskiego cieszą się wyjątkowym uznaniem $(\ldots)^{\prime 148}$.

${ }^{143}$ M. Ruszczyc, Ratownicy czasu wojny, „Tygodnik Powszechny” R; 30(1976) nr 7; por. A. Vetula ni, Arcypasterz krakowski na przelomie epok, s. 108; S. Rymar, Prace charytatywne kardynala Sapiehy, „Tygodnik powszechny" R: 7(1951) $\mathrm{nr} 46$.

${ }_{144}$ D. Pły gawko, Polonia..., dz. cyt., s. 105. Zastępcami Osuchowskiego byli: Andrzej Platrek-Zyberk oraz Józef Wierusz-Kowalski. Pierwszym sekretarzem był Erazm Piltz natomiast skarbnikiem Henryk Marconi. Oprócz tego do Komitetu wchodziło dodatkowych 14 czlonków.

${ }^{145}$ D. Płygawko, Sienkiewicz w Szwajcarii, dz. cyt., s. 146-147.

${ }^{146}$ AKKM, T. S. VI/ 23, List H. Sienkiewicza do bp. Adama Sapiehy z dnia 27 I 1915 roku.

${ }^{147}$ Tamże.

${ }^{148}$ Tamże. Zarówno Sienkiewicz jak i Osuchowski opowiadali się za apolitycznym kształtem Komitetu. Dlatego już w pierwszych miesiącach dzialalności doszło do rozłamu na tym tle pomiędzy Piltzem i wy- 
Aby osiągnąć wyżej wspomniany cel Komitet Veveyski opracował Odezwę do narodów cywilizowanych świata (1 II 1915). Ów apel przethumaczony był na kilka języków i został rozprowadzony po całym świecie (drogą telegraficzną). Autorem jej był Henryk Sienkiewicz, który przedstawił tragiczny stan ziem polskich i narodu polskiego, jakie spowodowała wojna. Pod koniec odezwy umieścił dramatyczne pytanie:

(...) Czyż ojczyzna moja, Polska, nie ma prawa do Waszej pomocy? Każdy naród nieszczęsny domagać się jej może w imię zasady odwiecznej, w imię milości bliźniego, naród polski jednak powoływać się także może na inne tytuly, które przemawiaja za nim przed światem. Otrzyma on wasza pomoc, ponieważ rozćwiartowany i zdobyty, nie sprzeniewierzyl się on nigdy slawnej swej przeszlości, nigdy nie przestal walczyć przeciwko brutalnej przemocy $(. .)^{149}$.

Komitet wydał jeszcze drugą odezwę - Apel Komitetu Generalnego, którą na prośbę Sienkiewicza i Osuchowskiego przygotował znany historyk prof. Szymon Askenazy. Odezwa ta składała się z trzech części, w których opisał działania zbrojne na polskich ziemiach. Przedstawił w sposób szczegółowy skutki wojny, zniszczenia miast i wsi oraz tragiczną sytuację ludności. Wspomniał także o bratobójczych walkach do jakich dochodziło na polu bitwy ${ }^{150}$.

Zarówno Komitet biskupa Sapiehy jak i Komitet w Vevey współpracowały ze sobą przez niemal cały okres wojny. Według koncepcji Adama Vetulaniego wątpliwym było, by Sapieha mógł zorganizować skuteczną pomoc dla poszkodowanych uzyskując wsparcie wyłącznie od samych Polaków. Dlatego też współpraca ta miała kluczowe znaczenie dla pozyskiwania zagranicznych funduszów ${ }^{151}$.

Biskup krakowski Sapieha i Henryk Sienkiewicz oddzielnie wysłali listy do ówczesnego papieża Benedykta XV z prośbą o błogosławieństwo dla nowych inicjatyw ${ }^{152}$. Sytuacja Stolicy Apostolskiej w pierwszym miesiącu wojny była powaźna, albowiem zmarł papież Pius X. Konklawe zebrało się w dwa tygodnie później i wybrało nowego papieża. Został nim kardynał Giacomo della Chiesa, który przybrał imię Benedykt XV. I choć planowano przełożenie koronacji nowo wybranego papieża na okres po skończeniu wojny, to jednak dnia 6 IX 1914 nastąpiła cicha koronacja w Kaplicy Sykstyńskiej. Rozpoczęty pontyfikat okazał się bardzo trud-

żej wspomnianym Sienkiewiczem. Piltz opowiadał się za włączenie Komitetu w sprawy polityczne.; por. D. Płygawko, Polonia..., s. 111; por. A. Tyszkiewicz, Nieznane listy H. Sienkiewicza do Adama Sapiehy. „Zeszyty historyczne”, Paryż, nr 131/2000, s. 221-229.

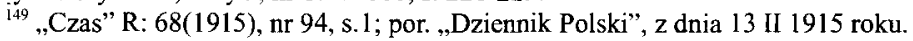

${ }^{150}$ D. Płygawko, Polonia.., dz. cyt., s. 110-111.

${ }^{151}$ A. Vetulani, Arcypasterz..., dz. cyt., s. 108.

${ }^{152}$ AKKM, T. S VI/ 23. Sienkiewicz wysłał list do papieża z prośbą o błogosławieństwo oraz modlitwę $w$ intencji Komitetu $i$ jego działań. 12 marca 1915 roku Sienkiewicz otrzymuje list od kardynała Pietro Gasparriego z Błogosławieństwem papieskim. W imieniu papieża opisał w nim zaniepokojenie jakie towarzyszy papieżowi wobec prowadzonych działań wojennych na terenie Polski. Pisze dalej że naród polski jest bardzo bliski Benedyktowi XV zwłaszcza ze względu na swoje oddanie dla Stolicy Apostolskiej. AKKM, TS VV/34, List kadr. P. Gassparri'ego do H. Sienkiewicza z dnia 12 III 1915; por. D. Płygawko, Benedykt XV dla Polski - 90-lecie papieskiej kolekty 21 listopad 1915, Poznań 2005, s. 50-52. 
nym w chwili, gdy działania wojenne pochłaniały całą Europę. Papież nieustannie przedstawiał apel o zaprzestanie działań wojennych (w miesiącach: IX, XII 1914 oraz V, VII, XII 1915 oraz III, VII 1916 oraz V, VII 1917). Apele papieża nie były jedynym przejawem jego działalności pasterskiej. Starał się także wspierać projekty pomocy organizowane przez różne komitety charytatywne. Udzielał im swojej pomocy duchowej jak i materialnej ${ }^{153}$.

Dnia 31 XII roku biskup Sapieha przesłał do Watykanu wraz z wcześniej ogłoszoną odezwą prośbę o poparcie papieskie dla nowego Komitetu. W niedhugim czasie (15 I 1915 roku) nuncjusz apostolski w Wiedniu abp Raffaele Scapinelli przesłał Sapieże pierwsze dary Ojca świętego oraz Kolegium Kardynalskiego. Ten zastrzyk w postaci pomocy finansowej dla rozwijającego się Krakowskiego Komitetu był zapowiedzią wydatnej pomocy Stolicy Apostolskiej dla narodu polskiego w czasie kolejnych lat wojny ${ }^{154}$.

Istotnym wsparciem działalności wspomnianych Komitetów była pomoc (głównie finansowa) Polonii amerykańskiej. Biskup krakowski w imieniu Książęco Biskupiego Komitetu wysłał odezwę do polskich biskupów w Stanach Zjednoczonych. Sapieha pisał także w imieniu całej Polski, gdyż jak wspominał „(...) jestem dziś prawie jedynym $\mathrm{z}$ biskupów mogących zabrać głos i połączyć się $\mathrm{z}$ zachodem, inni pogrążeni wśród rozszalejących bitew nie mogą sie odezwać (...)"155. Utrudniona komunikacja pomiędzy zaborami ograniczała dostarczenie poszkodowanym konkretnej pomocy. $\mathrm{Na}$ apel Sapiehy odpowiedziało wielu dobroczyńców zagranicznych - między innymi rodacy mieszkający w Stanach Zjednoczonych Ameryki. Pośrednio na przypływ funduszy od Polonii na konto Komitetu Veveyskiego jak i KBK miała misja Ignacego Paderewskiego. Podobnie jak w Paryżu i w Londynie Paderewski pragnął pozyskać dla sprawy polskiej jak największe koło zainteresowanych ${ }^{156}$. Dlatego 15 VI 1915 roku doszło do powstania w Nowym Yorku Funduszu Pomocy dla Polskich Ofiar - National American Comitte of the Polish Victim's Relief Fund. Na rzecz sprawy polskiej działały także: Polski Centralny Komitet Ratunkowy w Chicago oraz Komitet Marceli Sembrich - Kochań-

153 Z. Zieliński, Benedykt XV (1914-1922), [w:] Papiestwo i papieże dwóch ostatnich wieków, Warszawa 1999, s. 290-293; por. D. Płygawko, Benedykt XV..., dz. cyt., s. 46; por. A. Gianelli, A. Tornielli, Papieże a wojna - od pierwszego światowego konfliktu po atak na Irak, Kraków 2006.

${ }^{154}$ Trzy lata dziatalności KBK, s. 7.

${ }^{155}$ AKKM, T. S. VV/18, List bp. Sapiehy do biskupów w Stanach Zjednoczonych Ameryki b. d.

${ }^{156}$ D. Płygawko, Polonia ..., dz. cyt., s. 119-123. Przed przyjazdem do Stanów Zjednoczonych, Paderewski zakładał z ramienia Komitetu Veveyskiego filie w Paryżu i Londynie. W Paryżu był to Komitet „Pro Polonia”( "Comite Pro Polonia”) - do zarządu weszła m.in. Maria Curie Skłodowska. Natomiast w Londynie na początku 1915 roku powstał The Polish Victims Relief Fund. Cała organizacja jak i kierowanie późniejszą filią spoczywało w rękach Laurence Alma Tadema. Jej odezwy przyczyniły się w dużej mierze do przybliżenia Anglikom tragedii narodu polskiego. W 1914 roku wydała broszurę Poland, Russia and the War, w której pokazywała sytuację ludności polskiej w zaborze rosyjskim. Jej działania przyczyniły się do pozyskiwania znacznych funduszy, które przez Komitet Veveyski przesyłane były dla polskiej ludności w zaborze rosyjskim. Do 1917 roku filiom Komitetu Vevyskiego oraz wspomnianym organizacjom w Anglii udało się przesłać 1224271,35 fr. szw.). 
skiej $^{157}$. Wkład Polonii amerykańskiej w pomoc dla rodaków w kraju był ogromny. Warto podkreślić rolę jaką pełniła prasa informując mieszkańców zaborów o zagranicznej pomocy ${ }^{158}$. Te wiadomości przyczyniały się do poszerzania wiedzy Polaków w kraju o ofiarowywanej im przez Polonię pomocy. Przede wszystkim świadomość rodaków, że nie zostali pozostawieni samym sobie dodawała im otuchy.

Przedstawione powyżej inicjatywy miały ogromny wpływ na wspieranie mieszkających w zaborach Polaków. Pomoc finansową wszystkich wyżej wymienionych organizacji dla beneficjentów Książęco Biskupiego Komitetu zostanie omówiona $w$ jednym $z$ rozdziałów tej pracy.

\section{POWOEANIE KOMITETU I JEGO ORGANIZACJA}

Książę Biskup Sapieha jeszcze przed napływem darów starał się zorganizować prowizoryczną instytucję. Nieoficjalnie (według rozliczeń kasowych Komitetu) za początek działalności akcji przyjęto dzień 4 I 1915 roku $^{159}$. Sapieha (17 I 1915) przesłał powiadomienie do Naczelnej Komendy Armii (Oberkommando), informując w nim o powołaniu Komitetu. Sapieha uzyskał od arcyksięcia Fryderyka (naczelnego wodza wojsk austriacko-węgierskich) poparcie oraz deklarację dalszej współpracy ${ }^{160}$. Od tamtej pory Komitet mógł liczyć w różnych sprawach akcji ratunkowej na życzliwość i poparcie ze strony Komendy Armii. Dodatkowo arcyksiążę w liście do Sapiehy podał propozycję, by nowo powstały Komitet ściśle współpracował $\mathrm{z}$ akcją pomocy poszkodowanej ludności przygotowywaną przez rząd i wojskowość. Dzięki temu na ziemiach okupowanych z czasem uruchomiono administrację, której zadaniem było gromadzenie wszelkich informacji dotyczących klęski ludności oraz zapotrzebowania ludności co do określonej pomocy. Zarówno Namiestnik Galicji Korytkowski jak i bar. Eichoff ( $\mathrm{z}$ ramienia Głównej Komendy Etapowej) uważali, że pomiędzy obiema akcjami: rządową i biskupią, powinna przebiegać delimitacja, co jednocześnie nie wykluczało współpracy ${ }^{161}$.

${ }^{157}$ Tamże, s. 156- 157. Autorka wyczerpująco porusza sprawę organizacji pomocy przez Polonię dla Komitetu Veveyskiego.

${ }^{158}$ Skarb narodowy dzieci, "Głos Narodu” R: XXIII(1915), nr 370, s. 2. W prasie donoszono o inicjatywie Polonii amerykańskich dzieci: „Wychodzący w stanach Zjednoczonych „Przyjacicl dzieci” ogłosił odezwę aby dziatwa zbierała składki ze swych oszczędności na głodne dzieci w Polsce (...) każde dziecko w Amcryce powinno się starać aby na skarb narodowy ze swych oszczędności złożyło przynajmniej jednego dolara! Najłatwiej da się to zrobić w ten sposób, gdy w każdej klasie pod przewodnictwem nauczycielki utworzycie sobie komitet - który zajmie się stałym zbieraniem składek na skarb narodowy. Musicie uczyć się działać samodzielnie (...) Pamiętajmy jednak że ofiara musi być własna , nie wolno wam prosić rodziców o pieniądze na ten cel (...) Odezwa odniosła skutek..Wkrótce w Chicago nie będzie poiskiej szkoły w której by nie zbierano pieniędzy na ten cel (...)".

${ }^{159}$ R. M. Zawadzki, Biskup..., dz. cyt., s. 147.

${ }^{160}$ B. Przybys zewski, Adam Stefan..., dz. cyt., s. 89.

${ }^{16 i}$ Trzy lata dzialalności..., dz. cyt., s. 9-10. Baron Eichoff donosił Sapieże o powołaniu przez Namiestnictwo oraz Główną Komendę Etapową państwowej akcji zapomogowej która tworząc Komitety mogłaby rozdzielać przydzielone im zasiłki. 
Trafnymi stały się podane przez prof. Godlewskiego wytyczne pracy Komitetu: stworzenie planu działania, dobór członków oraz zarządzanie pracami komitetu $\mathrm{i}$ ich stały nadzór ${ }^{162}$. Początkowo Komitet pracował w oparciu o tzw. ,roboczy" status, który został ułożony na polecenie Sapiehy przez prof. UJ Stefana Jentysa ${ }^{163}$. Regulamin ten był potrzebny do wstępnej organizacji Komitetu. Przedstawiony on został ówczesnemu szefowi Głównej Komendy Etapowej gen. Kanikowi ${ }^{164}$. Regulamin ten został zaaprobowany przez władze wojskowe i dnia $19 \mathrm{~V} 1915$ roku Namiestnik Korytkowski zatwierdził statut Krakowskiego Biskupiego Komitetu Pomocy dla Dotkniętych Klęską Wojny (skrót KBK). Jednakże powszechnie przyjęła się także inna nazwa Komitetu - Książęco Biskupi Komitet Pomocy dla Dotkniętych Klęską Wojny. W późniejszych latach tą ostatnią Komitet uznał jako nazwę faktyczną instytucji ${ }^{165}$.

Jak już wcześniej wspomnieliśmy pierwszy statut KBK powstał w maju. Jego podstawą był zredagowany pierwotnie regulamin Komitetu. Regulamin posiadal 10 paragrafów, do których Namiestnictwo poprosiło o dołożenie jeszcze kolejnych pięciu. W sumie na I Statut KBK składało się 15 paragrafów, które określały cel Komitetu oraz jego strukturę. I Statut Krakowskiego Biskupiego Komitetu Pomocy dla Dotkniętych Kłęską Wojny w pełnej formie został podany w aneksie ${ }^{166}$.

$\mathrm{W}$ istocie najważniejszym punktem I Statutu było określenie celu, jaki przyświecał działalności Komitetu. Dzieło miłosierdzia, humanitarne, ale apolityczne. Odstąpienie od jakiegokolwiek udziału w grach politycznych i skierowanie wszystkich działań na tworzenie akcji pomocy dla ludności można uznać za naczelny sukces Komitetu. Komitet miał za zadanie nieść pomoc poszkodowanej ludności w Galicji i Królestwie Polskim. Wszystkie środki finansowe na te działania miały być pozyskiwane na drodze zbierania ofiar i datków a także poprzez wewnętrzne składki członków Komitetu.

Statut przewidywał także powołanie delegacji lokalnych, które bezpośrednio podlegając Komitetowi pośredniczyły w akcji pomocy poza Krakowem. Dodatkowo utworzono Sekcje, które posiadały określone zadania. Ponadto duże prerogatywy przysługiwały Sapieże jako przewodniczącemu. Komitet powoływał z grona swoich członków dwóch wiceprezesów oraz sekretarza i skarbnika. Razem we

${ }^{162}$ E. Godlewski, Dzialalność Księcia Metropolity Adama Stefana Sapiehy w okresie wielkiej wojny, [w:] Dwadzieścia pięć lat pasterzowania Księcia Metropolity A. S. Sapiehy. Jubileuszowa Ksiega pamiqtkowa, red. ks. F. Machay, Kraków 1937, s. 36-37.

${ }^{163}$ AKKM, T. S. VI/65, Projekt statutu Krakowskiego Biskupiego Komitetu Pomocy dla Dotkniętych Klęskq Wojny zatwierdzonego $19 \mathrm{~V} 1915$ roku; por. TS VI/65 a, Kopia projektu statutu Krakowskiego Biskupiego Komitetu Pomocy dla Dotkniętych Klęska Wojny zatwierdzonego $19 \mathrm{~V} 1915$ roku. Podany jest tam w całości wstępny regulamin.

${ }^{164}$ AKKM, T. S VI/39, Pismo K. und K. Ammeeoberkommando an Fürsorgeaktion des Fürstbischofs von Krakau. Generał Kanik otrzymał wstępny regulamin KBK 28 III 1915 roku. W odpowiedzi z dnia 3 kwietnia 1915 roku zapewniał Sapiehę min. o przychylności i wsparciu władz wojskowych w podejmowanych działaniach humanitarnych.

${ }^{165}$ Trzy lata dzialalnosici....., dz. cyt., s. 11.

${ }^{166}$ zob. ancks 1 , por. AKKM, T. S. VI/65, 65a, 
współpracy z przewodniczącym stanowili Komisję Nadzorczą, choć jej kompetencje w pełni dopiero określił kolejny statut. Istotnym był także zapis, że w razie rozwiązania komitetu Sapieha jako przewodniczący mógł dysponować jego majątkiem wedkug swojej woli.

KBK ze względu na współpracę $z$ gen. Kanikiem udało się pomyślnie uzyskać wszystkie potrzebne pozwolenia. Miedzy innymi Główna Komenda Etapowa rozdawała legitymacje członkom, które pozwalały im podróżować (w celach zbierania informacji) po okupowanych terenach. Komitet otrzymal także automobil osobowy i ciężarowy (z przydzielonymi do nich szoferami), a także międzymiastową stację telefoniczną. Dodatkowo wojskowe transporty polowe miały ułatwiać wysyłanie wszelkich przesyłek opieczętowanych przez KBK ${ }^{167}$.

$\mathrm{Na}$ czele Komitetu stał biskup Sapieha będący jednocześnie pomysłodawcą i twórcą KBK. Podjął się on trudnej pracy jaką było zarządzanie i koordynowanie prac Komitetu. Uprawnienia, które dawał status Sapieże wynikały przede wszystkim $z$ wielkiego autorytetu, który posiadał u rzeszy ludzi. To Sapieha miał głos decydujący przy wszystkich istotnych i spornych zagadnieniach. Przy tak dużej władzy, jaką Sapieha posiadał w Komitecie nie przestał być przystępnym dla każdego, kto szukał u niego-pomocy. Wśród współpracowników wzbudzał on podziw i szacunek oraz gotowość do ciężkiej pracy. Jeden z jego współpracowników, prof. Godlewski, przedstawił zarys sylwetki Sapiehy:

(...) Książę Biskup Sapieha był istotnie nie tylko przewodniczącym Komitetu, każdy kto w tym zespole ludzi pracował, pamięta i czuł przez cały czas tej pracy, że On był jej duszą, inicjatorem rozlicznych poczynań, a interesował się naprawdę nawet drobniejszymi szczegółami działalności, starał się wszystkim współpracownikom ułatwiać usuwanie trudności w pracy, wpływami swymi u władz ówczesnych pomagać, łagodzić tarcia, których się w takich razach nie raz nie da ominąć. Każdy współpracownik Komitetu mógł być pewien, że w razie potrzeby autorytet i wplywy Księcia Biskupa będą przez niego użyte, ażeby mu dopomóc $(. . .)^{168}$.

\section{CZEONKOWIE KBK}

Jednym ze źródeł sukcesu Książęcego Komitetu byli jego, trafnie dobierani przez Sapiehę członkowie. On sam wspomniał o tym pisząc: „(...) Założyłem KBK. W klerze i strefach katolickich mimo szukania nie znalazłem ofiarnych. Po próbach kilku musiałem udać się do innych ludzi z dala od Kościoła stojących któ-

${ }^{167}$ AKKM, T. S. VI/37, Pismo K. u k. Etappenberkommando do Fürsterzbischöflichen Gnaden, Fürsten Sapieha nach 21 III 1915. Między innymi w liście Etappenberkommando informowało Sapiehę o przydzieleniu mu automobilu; por. Trzy lata dzialalności $K B K$, s. 14. W czasie istnienia Komitetu nie udało się uzyskać od władz zniesienia opłat za koszty transportu.

${ }^{168}$ E. Godlewski, Dzialalność Księcia.., s. 39; por. A. Baciński, Dzialalnośćc.., s. 269. 
rzy okazali się doskonałymi pracownikami i ludźmi bardzo porządnymi. Popularność jaka otoczyła KBK oddziaływała też na stosunki diecezjalne bano się występować przeciwko mnie (...)"169. Na członków Książęco Biskupiego Komitetu Sapieha powoływał przede wszystkim osoby, które odznaczały się wysokim stopniem pracowitości, autorytetem i oddaniem dla sprawy pomocy ludności. Jego bliski przyjaciel abp Teodorowicz tak go określił: „,...) Sapieha umiał milczeć nie wywnętrzał się, był w ogóle ostrożny wobec ludzi, posiadając przy tym dar ich znajomości, a przede wszystkim umiał w przeprowadzeniu sprawy - nie wysuwając się nigdy na czoło - chować siebie w cień (...)"170.

$\mathrm{Na}$ członków Komitetu Sapieha powoływał zarówno osoby duchowne jak i świeckie. W poczet pierwszych członków wybranych w styczniu 1915 roku wchodzili: ks. arcybiskup Franciszek Albin Symon ${ }^{171}$, ks. Marceli Ślepicki ${ }^{172}$, ks. Czesław Wądolny ${ }^{173}$, Władysław książę Sapieha ${ }^{174}$, Wilhelm Seidl, Wacław Anczyc $^{175}$, Witold książę Czartoryski, Michał Garapich, Emil Godlewski starszy ${ }^{176}$, Stefan Jentys ${ }^{177}$, Kazimierz Kostanecki ${ }^{178}$, Kazimierz Morawski. Każda z tych osób swoimi zdolnościami i na miarę swoich możliwości pragnęła pomóc w akcji Komitetu.

Trzeba też zaznaczyć, że ich praca była czysto honorowa, dlatego nie pobierali oni żadnych diet czy pensji (natomiast jeśli chodzi o wyjazdy w celach służbowych zwracano im koszty podróży) ${ }^{179}$.

Komitet przez pierwsze miesiące koncentrował się na tworzeniu struktur i gromadzeniu napływających funduszy ze świata. Dlatego inne plany organizacyjne, jak np. powołanie nowych sekcji, odeszły na dalszy plan. Z tego też powodu prezydium KBK powołano dopiero w marcu 1915 roku. Zastępcami Sapiehy zostali: ks. abp Franciszek Symon oraz rektor Kazimierz Kostanecki. Do Komisji nadzorczej weszli prof. Jentys, książę Władysław Sapieha oraz dyrektor Michał Garapich. Co się zaś tyczy funkcji sekretarza prezydialnego został nim dr Jan Górski (nie będący jeszcze wówczas członkiem KBK) ${ }^{180}$.

\footnotetext{
${ }^{169}$ AKKK, Dziesięć lat...

${ }^{170}$ J. Teodorowicz, Dzialalność Księcia Metropolity Adama Stefana Sapiehy w okresie wielkiej woj$n y$, [w:] Dwadzieścia pięć lat pasterzowania Księcia Metropolity A. S. Sapiehy. Jubileuszowa Księga pamiątkowa, red. ks. F. Machay, Kraków 1937.

${ }^{171}$ Zob. E. Wyczawski, Symon Albin Franciszek, [w:] Slownik polskich teologów katolickich, vol. 4, Warszawa 1973, s. 237-239.

${ }^{172}$ zob. M. Jagosz, Slepicki Marceli, [w:] Slownik polskich teologów katolickich, vol. 7, Warszawa 1983, s. 278-279.

${ }^{73}$ Zob. Gabryel, Wadolny Czeslaw, [w:] Slownik polskich teologów katolickich, vol. 4, Warszawa 1973 , s. $400-401$.

${ }^{174}$ Zob. Z. Fras, Wladysiaw Leon Sapieha. PSB, s. 158-160.

${ }^{175}$ J. Adamczewski, Mala encyklopedia Krakowa, Kraków 1996.

${ }^{176}$ Zob. B. Hryniewski, Emil Godlewski starszy, PSB VIII, s. 172-173.

${ }^{177}$ Zob. F. Górski, Stefan Jentys, PSB XI, s. 173-174.

${ }^{178}$ Zob. Stanisław Kohmann, Kazimierz Kostanecki, PSB XIV, s. 330-332.

${ }^{19}$ Trzy lata..., dz. cyt., s. 8-9.

${ }^{180}$ Tamże, s. 30-31.
} 
Już po kilku miesiącach regulamin, a później statut KBK okazał się nie wystarczający, by prace Komitetu mogły przebiegać w sposób efektywny. Przy ich tworzeniu nie przewidziano bowiem, że ogrom wojny będzie wymagał coraz większych nakładów pracy oraz że pomoc będzie musiała być obliczona na co najmniej kilkanaście miesięcy. Dlatego też potrzebne były zmiany w administracji. Palącą potrzebą okazało się znalezienie nowej siedziby dla wciąż rosnącej struktury organizacji. Powstające agendy miały swoją siedzibę w pałacu biskupim oraz w dwóch pokojach ks. Ślepickiego ${ }^{181}$. Ks. Ślepicki początkowo nie wynajmował dodatkowego biura dla KBK, gdyż dochodziłyby wtedy nowe koszty utrzymania. Prawdopodobnie było to świadomie zastosowane rozwiązanie tymczasowe, które było wprowadzone na czas potrzebny do przekonania się, jak wielkie będzie zapotrzebowanie na pomoc $i$ jak długo będzie trwała wojna. Pod koniec 1915 roku rozpoczęto wprowadzanie zmian. Przeniesiono Biuro KBK do mieszkania przy ulicy Wolskiej. Mieściło się ono tam do roku 1917, w którym to przeniesiono je na ulicę Kapucyńską, do jeszcze większego lokalu ${ }^{182}$.

Komitet musiał sobie poradzić $z$ kolejnym wyzwaniem $-\mathrm{z}$ pozyskaniem płatnych urzędników i funkcjonariuszy do pracy w Komitecie. W niedhugim czasie okazało się, że jedna osoba nie mogła sprostać wielości zadań, jakie wynikały $z$ rozwoju administracyjnego ${ }^{183}$. Stąd powołano głównego księgowego KBK, którym został Jerzy Gawroński, a który po kilku miesiącach pracy okazał się niezrównanym specjalistą w stosunkach handlowych (m.in. w sprowadzaniu i zakupie towarów). Kierownictwo biura KBK objął ks. Michał Wojtusiak. Założono także archiwum KBK, którym zarządzała Józefa Dorniakówna. W Trzech latach dziatalności KBK tak scharakteryzowano pracę urzędników:

(...) Trzeba by dhugo pisać gdyby się chciało wspominać o wszystkich urzędnikach KBK którzy na uznanie lub wdzięczność za uczciwa pracę i sumienne wykonywanie obowiązków zasługują. Większość ich pojmuje swe zajęcia nie jako sposób zdobywania sobie chleba powszedniego, lecz uważa je za obowiązek obywatelski, który nie tylko w godzinach biurowych, ale gdy tylko tego potrzeba, i poza godzinami biurowymi, chętnie spełniać pragnie $^{184}$.

Z początkiem roku 1916 postanowiono zmodyfikować istniejący statut KBK. Po pierwsze brakowało Wydziału Wykonawczego. Do 1916 roku, Książę Biskup jako przewodniczący KBK, podejmowal błyskawiczne decyzje we wszystkich sprawach bieżących. Jednakże Sapieha uznawał, że spoczywała na nim zbyt duża odpowiedzialność, dlatego dokooptował kilku członków i razem rozpatrywali

${ }^{181}$ Trzy lata.. , s. 30-31. Do początku listopada mieściła się tam Kasa Główna oraz biuro sekretariatu.

${ }^{182}$ Tamże, s. 30-32.

${ }^{183}$ Tamże, s. 64. Przykład p. Tadeusza Rządcy który do połowy 1915 roku pracował w Sekretariacie później jednak zajął się pracą w Fabryce Taniego Obuwia.

${ }^{184}$ Trzy lata.., s. 65. 
wszelkie naglące wnioski. Powstanie Wydziału Wykonawczego pociągnęło za sobą jeszcze jedną ważną reformę, jaką była likwidacja jednego stanowiska wiceprezesa. Od tej godności odstąpił ówczesny wiceprezes rektor Kostanecki. W myśl nowego statutu jedynym wiceprezesem pozostał ks. abp Franciszek Symon. Wprowadzone zmiany i uzupełnienia do nowego statusu zostały usankcjonowane przez prezydium KBK i dnia 1 II 1916 roku przesłano do Namiestnictwa nowy statut do zatwierdzenia. Miesiąc później Komitet mógł działać już według nowego II Statutu Książęco Biskupiego Komitetu Pomocy ${ }^{185}$.

Nowy status przewidywał zwiększenie liczby członków, gdyż liczba wcześniejszych 13 członków nie była wystarczającą dla potrzeb Komitetu. Dnia 11 III biskup Sapieha powołał na członków KBK: prof. Emila Godlewskiego młodszego, prof. Karola Kleckiego, prof. Leona Marchlewskiego, dr. Jana Górskiego, ks. dr. Józefa Niemczyńskiego, panów: Tadeusza Rzącę, Władysława Studzińskiego, Mieczysława Szybalskiego oraz Tadeusza Żuka - Skarszewskiego. Większość z powołanych członków KBK pracowała już wcześniej dla KBK ${ }^{186}$. Jednakże ze względu na obowiązujący wtedy stary statut nie mogli oni zostać powołani na nowych członków KBK ${ }^{187}$. Nowy statut nakładal więcej obowiązków na współpracowników KBK. Pomimo wprowadzonych zmian Sapieże udało się utrzymać silną pozycję w Komitecie.

W 1917 roku skład osobowy KBK wynosił 22 członków. Do Wydziału Wykonawczego należeli: bp Adam Stefan Sapieha. Wacław Anczyc, dr Jan Górski, prof. Karol Klecki, prof. Leon Marchlewski oraz Tadeusz Rząca. W połowie roku 1917 zarówno prof. Kleckiego jaki i Marchlewskiego zastąpili inż. Władysław Kucharski oraz prof. Emil Godlewski m. ${ }^{188}$ Posiedzenia odbywały się dwa razy w tygodniu. Wydział zajmował się przede wszystkim bieżącymi formalnościami, przyjmował wnioski o pomoc, przydzielał zapomogi. Wprowadzano także zmiany w Komisji Nadzorczej. W chwilach, kiedy bp Sapieha nie mógł uczestniczyć w obradach początkowo zastępował go prof. Marchlewski. Kiedy jednak odszedł z Ko-

${ }^{185} \operatorname{Trzy}$ lata..., s. 66-67. Namiestnictwo nie odpowiedziało na statut, gdyż w myśl ustawy o stowarzyszeniach jeśli statut nie zostanie odrzucony przez namiestnictwo w ciagu 4 tygodni zostaje on zatwierdzony; zob. aneks 2.

186 TS VI/ 31. Przykładem współpracy nie potwierdzonej członkostwem była pomoc w pracach Komitetu Jana Górskiego. W liście do Sapiehy z dnia 11 III 1915 roku W. Czartoryski zwracał uwagę na poszczególne osoby, które podjęły by się pracy na rzecz Komitetu. „(...) Dalej na dra Jana Górskiego który się tymi dniami do Ciebie zgłosi i w razie że tego żądasz gotów jest służyć w jakiejkolwiek formie, nawet bez kooptacji. By on urzędnikiem u Jaworskiego, lecz wystąpił- nie zna się zupełnie na rzeczach praktycznych, ale ma dobre pióro mówi doskonale po niemiecku i francusku. Uważam go za bardzo szlachetnego człowieka zdolnego do poświẹcenia się zupełnie sprawie. Mógłby być używany do mówienia z władzami zna dobrze Królestwo - pisanie itd. B. pilny pracownik".

${ }^{187}$ Trzy lata.., s. 70-71. Na rzecz Komitetu pracowali już weześniej dr J. Górski, radca Szybalski zastąpił na stanowisku Sekcji opieki nad dziećmi po śmierci p. Seidla. W roku 1917 odeszli z KBK Książe Witold Czartoryski oraz powołany do sekcji sanitarnej dr Góral ze względu na bierny udział w pracach Komitetu. W 917 roku umarł także M. Garapich. W jego miejsce Sapieha zamianował inż. Władysława Kucharskiego.

${ }^{188}$ Tamże, s. 71. Jest tam podany szczegółowo skład członków KBK. 
mitetu wyżej wspomniany prof. Marchlewski, Książę Biskup nie wyznaczył nikogo na swojego zastępcę ${ }^{189}$.

Wszystkich współpracowników Sapiehy charakteryzowała wyjątkowa pracowitość, bezinteresowność oraz oddanie akcji pomocy społeczeństwu. Większość pracowników Komitetu wywodziła się z Uniwersytetu Jagiellońskiego. Pod koniec 1917 stanowili oni $50 \%$ składu zarządu KBK ${ }^{190}$. Społeczność akademicka w tych trudnych miesiącach wojny próbowała podjąć działania, które miały by na celu przeciwdziałanie tragedii, jaka dotknęła naród polski. Oczywiście jak w każdej pracy zespołowej pojawiały się problemy czy napięcia. Niemniej jednak Sapieha potrafił $w$ takich sytuacjach swoim opanowaniem i autorytetem łagodzić wszelkie spory. W swoich wspomnieniach prof. Godlewski pisze: „Miał książę biskup zdolność oceny ludzi: dobór był przeważnie trafny, a w razie pewnej omyłki przy najbliższej sposobności znajdowało się na gorzej obsadzone miejsce nowego człowieka, względnie w inny sposób dociągało się dany dział do odpowiedniego poziomu"191.

\section{SPRAWA RELACJI KBK Z NKN}

Nowo powołany Komitet KBK swoim zasięgiem jak i organizacją stawał się potężną organizacją na ziemiach polskich. Jednak w miarę rozwoju Komitetu w ciągu kilku lat wojny pojawiały się liczne ataki ze strony kręgów politycznych czy organizacji rządowych. Początkowo domagały się od Sapiehy jednoznacznej deklaracji co do kierowanego przez niego Komitetu. Później starano się go namawiać, by określił swoje stanowisko polityczne. Te ostatnie działania zaczęły przybierać formę działań zaczepnych wobec Sapiehy, KBK jak i współpracującego z nimi Komitetu Veveyskiego. Komitet będący w swoich założeniach apolityczny sprzeciwiał się jakimkolwiek grom politycznym. Głównym przeciwnikiem instytucji był NKN. Należy podkreślić, że na wiadomość o powołaniu Naczelnego Komitetu Narodowego Sapieha wyraził poparcie dla tej organizację udzielając jej 10000 koron subwencji. Kiedy jednak w kilka miesięcy później NKN zaczął przybliżać się do idei socjalistycznych Sapieha definitywnie się od niego odciął. Na jakiekolwiek naciski ze strony NKN co do deklaracji politycznej Sapieha odpowiadał, że pragnie wolnej, suwerennej Polski ${ }^{192}$. Po latach Sapieha napisze w swoich wspomnieniach o NKN: „Zaraz na początku stanąłem przeciw robocie NKN jako podstępnej nieuczciwej. Odtąd też rozłam z partją konserwatywną stał się głębszy, otwartszy. Nie mogąc mnie zwalczać otwarcie szyto buty, potajemnie głównie sta-

${ }^{189}$ Trzy lata.., s. 72. Do 1916 roku w Komisji Nadzorczej pracowali prof. Stefan Jentys, Michał Garapich oraz książę Wladysław Sapieha. W zastępstwie księcia Sapiehy pracował ks. Czesław Wądolny który zrezygnował z początkiem 1916 roku. W myśl nowego statutu biskup Sapieha powołał do Komisji p. Jana Krzyżanowskiego oraz Wiktora Gablenza.

${ }^{190}$ M. Barcik, Udzial Uniwersytetu Jagiellońskiego $w$ akcjach spoteczno- filantropijnych $w$ latach 1914-1921, „Studia Historyczne”, R. XXVIII:1985, z. 4 (111), s. 577-595.

${ }^{191}$ E. Godlewski, Dzialalność Księcia.., s. 38.

${ }^{192}$ R. M. Zawadzki, Biskup ..., s. 149. 
rano się wzbudzić nieufność władz wojskowych. Dzięki jednak stosunkom z najwyższymi sferami rządowymi mimo wszystko udało się bez większych nieprzyjemności przejść ten czas może łatwiejszy jak przyszły (...)"193. Podobnie we wspomnieniach ks. Niemczyńskiego znajdziemy szereg wpisów na temat zatargów NKN z KBK: „Książę Biskup ma dużo nieprzyjemności ze strony różnych ludzi. Np. puszczano wiadomości jakoby KBK miało być rozwiązane ze względów politycznych, albo opowiadają że KBK wejdzie na tory polityczne i w Galicji polityką obecnie kierować będzie. Wszystko to są plotki bez podstawne, gdyż z początku Książę Biskup zaznaczył że dalekim będzie od polityki w tymże Komitecie i Krakowie i tego tenże się trzyma (...)"194.

Do najgłośniejszego ataku doszło na początku 1916 roku, kiedy to w swoim artykule p. Hupka (konserwatysta galicyjski - przychylny NKN) poddał krytyce Książęco Biskupi Komitet na czele $\mathrm{z}$ biskupem Sapiehą oraz Komitet Veveyski z Henrykiem Sienkiewiczem. Sytuację tę swego czasu opisał hr. Zygmunt Lasocki: „(...)P. Hupka jest widocznie bardzo dumny $z$ artykułu swojego pod tytułem KBK a NKN który umieścił w „Wiadomościach Polskich”. Pisze o nim pod datą 30 I 1916: (...) Artykuł jak ze wszystkich stron słyszę zrobił kolosalne wrażenie. Reforma go przedrukowała pod tytułem "Dwa Komitety" ze wszystkich stron otrzymuję powinszowania (...)". Zaś pod datą 4 II napisał: „(...) Wrażenie mojego artykułu rośnie z dniem każdym. O niczym innym teraz nie mówią" ${ }^{\prime 195}$. Lasocki potępiał krytykę dr. Hupki wspomniał też, że wyraził się on z ironią na temat medalu „Polonia devastata” (został wybity na cześć Sapiehy, Sienkiewicza oraz Paderewskiego, z którego dochód przeznaczono na cele charytatywne). Pisał dalej, że pan Hupka „(...) wspomina że: „od KBK do Czerwonego Krzyża i innych filantropijnych organizacji wieje ku NKN mroźny wiatr niechęci gdyż stamtąd, pochodzą kłody i kamienie rzucane prosto naszym pod nogi. I jaki tego powód? Dlaczego ta niechęć do NKN ? Domyślamy się głównie dla tego że w nim i koło niego skupiły sie przeważnie grupy demokratyczne (...)». Dalej wywodzi żale z powodu rzekomych zarzutów od których słuchania mróz idzie po kościach: «że NKN buduje jakąś socjalistyczną i żydowską Polskę a takiej lepiej by nie było». Wreszcie wezwanie Naszym dostojnym i czcigodnym wielce dotychczasowym przeciwnikom - tym $z$ medalu Polonia devastata - radzimy szczerze by sie starali wraz z nami zasłużyć sobie także na inny tytuł wdzięczności narodu (..." ${ }^{196}$. Wystąpienie Hupki przeciwko trzem największym postaciom oddanym sprawie polskiej w czasie I wojny światowej wywołało wśród opinii publicznej niesmak i dezaprobatę ${ }^{197}$. Biskup Sa-

${ }^{193}$ AKKK, Dziesięć lat...

${ }^{194}$ AKKM, Liber..., z dnia 15 września 1915 roku.

${ }^{195}$ Z. Lasocki, Spoleczeństwo polskie w czasie wielkiej wojny, w świetle pamiętnika dr Hupki, Kraków 1937 , s. 20 .

${ }^{196}$ Tamże, s. $20-21$.

${ }^{197}$ AKKM, Liber., z dnia 2 II 1916. „Dnia 2 lutego pojawił się w «Nowej Reformie» artykuł odpisany z wiadomości polskich piotrkowskich o stosuntu XBX do NKN napisany prezer posta Huphe. Whiciagu a tego 
pieha poczuł się dotknięty tymi pomówieniami, dlatego zerwał negocjacje z sekcją szpitalną NKN, w ramach której miano tworzyć wspólnie z KBK szpitale dla legionistów ${ }^{198}$.

Na drugi artykuł zareagował Henryk Sienkiewicz:

Prawie od początku swego istnienia komitet polski działający w Vevey stał sie przedmiotem napaści ze strony pewnych ludzi, którzy, nie zdoławszy wciągnąc nas w krąg własnej polityki, zarzucają nam że prowadzimy inną wprost przeciwną. Po długiem i cierpliwem milczeniu biorę pióro do ręki by przedstawić we właściwym świetle naszą działalność(...) Chodzi mi o to aby ogół polski dowiedział się dokładnie , jak rozumiemy tę służbę której podjęliśmy się dla dobra kraju(...) Obecnie jednak istnieje zadanie może ze wszystkich najważniejsze a jest nim ratunek dla zagrożonego polskiego życia. To właśnie zadanie wytknął sobie nasz Komitet Szwajcarski i z drogi która wiedzie do tego celu, nie zbacza i nie zboczy ani na prawo ani na lewo ${ }^{199}$.

Trafnego podsumowania dokonał poseł Lasocki pisząc ,(...) Pan Hupka pisze dość optymistycznie: „W Głosie Narodu ukazał sie artykuł H. Sienkiewicza będacy oględną bardzo odpowiedzią na mój art. O dwóch komitetach (...)"Oględna bardzo odpowiedź? W tym wypadku jest p. Hupka bardzo nie wymagający. KBK nie odpowiedział wcale p. Hupce. Miał co innego do roboty: ratowanie ofiar wojny (...) ${ }^{\$ 200}$. Pomimo szykan ze strony NKN i osób im sprzyjających zarówno Sapieha jak i członkowie Komitetu nie zaprzestali swojej działalności, a nie odpowiadając wprost na pomówienia swoją pracą, potwierdzali szlachetność motywacji leżących u źródeł przeprowadzanych akcji.

W takiej sytuacji można zadać pytanie: co było celem ataków i pomówień ze strony NKN? Rozgłaszanie plotek prawdopodobnie miało podważyć status Komitetu jak i samego Sapiehy wśród społeczeństwa. Jakkolwiek głównym powodem mogło być postrzeganie Krakowskiego Komitetu czy Komitetu Veveyskiego jako przeciwników politycznych (co do sprawy konfliktu pomiędzy Komitetem Veveyskim a NKN, sprawa była bardziej skomplikowana) ${ }^{201}$. Stąd można tłumaczyć fakt,

\footnotetext{
stosunku zwalczania NKN przez KBK. Wielkie oburzenie ten artykuł wywołał...Ponieważ KBK nie zajmuje się zupełnie polityką .Złośliwi rozpuszczają wieści najrozmaitsze o KBK. Na przykład że nie wolno będzic wolno zbierać składek na KBK, że KBK będzie zamknięte (...)".

${ }^{198}$ D. Płygawko, Polonia ..., dz. cyt., s. 147. Dodatkowo Sapieha domagał się przeprosin w związku z pomówieniami.); por. P. Żółtowski, Wspomnienia o kardınale Adamie Sapieże, „Nasza Przeszłość”, t. XXXVIII, Kraków 1972, s. 228-232. Podany jest tam jeszcze jeden przyklad dla którego NKN nie mogło pogodzić się z zaistniałym stanem rzeczy. W pamiętniku p. Hupki często pojawił się zarzut co do sprawy biskupa Bandurskiego, którego to według tego posła Sapieha wraz z bp. Teodorowiczem nie zgadzali się na jego wyjazd na front do oddziałów legionowych.

${ }_{199}$ W sprawie Komitetu Generalnego w Vevey, ,Głos Narodu” R: XXIV (1916), nr 72, s. 2.

${ }^{200}$ Z. Lasocki, Spoleczenstwo..., dz. cyt., s. 21.

${ }^{201}$ D. Plygawko, Polonia.., dz. cyt., s. 138-148.
} 
że nie wierzono w zapewnienia apolityczności i nieustannie domagano się oświadczenia, co do kierunku politycznego. Niechęć kręgów NKN mogła też wynikać ze sławy i szacunku z jakim odnosiło się społeczeństwo do wielkich jałmużników narodu polskiego. $Z$ pewnością nie jeden raz ten fakt podsycał w kręgach NKN chorobliwą zazdrość, ale także utrudniał on przedstawianie w złym świetle biskupa krakowskiego. Postać niezłomnego Sapiehy wobec zakusów NKN była godna podziwu. Wyróżniała się ona świadomą niezależnością opinii oraz śmiałością wypowiedzi. Brzydząc się kłamstwem, wszelkiego typu knowaniami, obłudą czy przesadą Sapieha potrafił trafnie oceniać ludzi oraz wyczuwać sytuację. Prof. Godlewski po wojnie napisał o nim :

(...) Jak zwykle w czasie terroru i wszelkiego rodzaju dyktatur, tak i w tamtych czasach spotykało się mnóstwo ludzi, którzy ciągle czegoś albo kogoś się bali. Przez cały okres działalności Komitetu patrząc na działalność naszego Przewodniczącego mieliśmy podniosłe wrażenie, ze wówczas On nigdy i nikogo się nie bał, a zawsze Mu chodziło o dobro instytucji, którą kierował i ludzi dla których pracowat ${ }^{202}$.

Te ataki z perspektywy czasu można też odczytać jako pewnego rodzaju „zabezpieczenie" przed ewentualnym skierowaniem Komitetów (ich członków) na drogę polityczną. Prawdopodobnie dodatkowo wrogość NKN podsycał dziennik prokoalicyjny jakim był „Głos Narodu”. Za błędną opinię przyjmowano jakoby Sapieha był właścicielem tej gazety. W 1913 z ramienia docenta UJ Adama hr. Żółtowskiego oraz ówczesnego kanclerza kurii ks. Nikla zawiązano nową spółkę wydawniczą. W czasie wojny „Głos Narodu” uważano za organ KBK ze względu na jego powiązania ze stronnictwem chrześcijańsko-społecznym oraz z samym Sapiehą. Na początku wojny gazeta nie miała dyrektora naczelnego (dr Antoni Beapuré został internowany przez władze rosyjskie). W porozumieniu z Sapiehą powołano komitet redakcyjny, na czele którego stanął prof. Stefan Jentys. Był on związany z tzw. centrum w Sejmie Galicyjskim. „Głos Narodu” od 1915 roku wychodził trzy razy dziennie. Na początku wojny określany był jako dziennik katolicko-demokratyczny. Pod koniec określano go natomiast jako bezpartyjny pod hasłem: „Nic ponad dobro narodu!". Charakterystykę jego w czasie wojny można streścić w słowach: ,(...) Otrzymał upomnienia nie za to co pisał lecz i za to czego nie pisał, upomnienia z powodu braku zapału c. k. patriotycznego. Żył pod grozą konfiskat i zawieszenia. Możliwe było jedynie robienie nastrojów, sugerowane czytelnikom"203.

E. Godlewski, Dzialalnośćc.., dz. cyt., s. 46.

C. Lechicki, Krakowski Glos Narodu w l. 1914-39, „Studia Historyczne” R:1973, s. 343. 